University of Nebraska - Lincoln

DigitalCommons@University of Nebraska - Lincoln

Papers in the Earth and Atmospheric Sciences

Earth and Atmospheric Sciences, Department

2011

\title{
A regional-scale climate reconstruction of the last 4000 years from lakes in the Nebraska Sand Hills, USA
}

Jens Schmieder

University of Nebraska-Lincoln, jens.schmieder@gmail.com

Sherilyn C. Fritz

University of Nebraska-Lincoln, sfritz2@unl.edu

James B. Swinehart

University of Nebraska-Lincoln, jswinehart1@unl.edu

Avery L. C. Shinneman

University of Nebraska-Lincoln

Alexander P. Wolfe

University of Alberta, awolfe@ualberta.ca

See next page for additional authors

Follow this and additional works at: https://digitalcommons.unl.edu/geosciencefacpub

Part of the Earth Sciences Commons

Schmieder, Jens; Fritz, Sherilyn C.; Swinehart, James B.; Shinneman, Avery L. C.; Wolfe, Alexander P.; Miller, Gifford; Daniels, N.; Jacobs, K. C.; and Grimm, Eric C., "A regional-scale climate reconstruction of the last 4000 years from lakes in the Nebraska Sand Hills, USA" (2011). Papers in the Earth and Atmospheric Sciences. 318.

https://digitalcommons.unl.edu/geosciencefacpub/318

This Article is brought to you for free and open access by the Earth and Atmospheric Sciences, Department of at DigitalCommons@University of Nebraska - Lincoln. It has been accepted for inclusion in Papers in the Earth and Atmospheric Sciences by an authorized administrator of DigitalCommons@University of Nebraska - Lincoln. 


\section{Authors}

Jens Schmieder, Sherilyn C. Fritz, James B. Swinehart, Avery L. C. Shinneman, Alexander P. Wolfe, Gifford Miller, N. Daniels, K. C. Jacobs, and Eric C. Grimm 


\title{
A regional-scale climate reconstruction of the last 4000 years from lakes in the Nebraska Sand Hills, USA
}

\author{
J. Schmieder, ${ }^{1}$ S. C. Fritz, ${ }^{1}$ J. B. Swinehart, ${ }^{2}$ A.L.C. Shinneman, ${ }^{1}$ A. P. Wolfe, ${ }^{3}$ \\ G. Miller, ${ }^{4}$ N. Daniels, ${ }^{4}$ K. C. Jacobs, ${ }^{1}$ and E. C. Grimm ${ }^{5}$ \\ 1. Department of Earth and Atmospheric Sciences, University of Nebraska-Lincoln, Lincoln, NE 68588-0340, USA \\ 2. School of Natural Resources, University of Nebraska-Lincoln, Lincoln, NE 68588-0517, USA \\ 3. Department of Earth and Atmospheric Sciences, University of Alberta, Edmonton, AB T6G 2E3, Canada \\ 4. Institute of Arctic and Alpine Research and Department of Geological Sciences, \\ University of Colorado, Boulder, CO 80309, USA \\ 5. Illinois State Museum, Research and Collections Center, Springfield, IL 62703, USA
}

Corresponding author - J. Schmieder, tel 402 440-1132, fax 504 488-6292, email jens.schmieder@gmail.com

\begin{abstract}
High-resolution paleohydrological reconstructions were carried out in five shallow lakes in the Nebraska Sand Hills across an east-west transect in order to 1) determine whether long-term droughts of the past 4000 years were spatially and temporally coherent across the region, 2) distinguish local variation in climate or hydrology from regional patterns of change, and 3) compare the paleolimnological results with the existing dune-inferred drought records. Diatom-inferred lake-level was reconstructed for all sites and compared with other regional records. Alterations between high and low lake-levels were frequent during the past 4000 years, which suggests that shifts between dry and wet periods were prevalent across the Sand Hills. Extended multi-decadal to centennial-scale droughts were more common prior to 2000 years BP, while the last two millennia were hydrologically more variable and climate conditions alternated on shorter timescales. Despite some discrepancies among the five records, the paleohydrological reconstructions refine the Holocene drought history of the Nebraska Sand Hills, particularly between 2200 and $4000 \mathrm{cal}$ a BP. Many of the observed drought events are contemporaneous with severe droughts documented at sites in the northern Great Plains and Rocky Mountains, lending support for the severity and regional significance of these events in western North America.
\end{abstract}

Keywords: Nebraska Sand Hills, droughts, lakes, diatoms, Holocene, Great Plains, paleolimnology

\section{Introduction}

The continental interior of North America hosts a large number of drought-sensitive eolian landscapes, and drought reconstructions from these active or episodically active areas can provide insight into the natural variability and magnitude of past drought (Forman et al., 2001). The Nebraska Sand Hills (Figure 1a) represent the largest contiguous grassstabilized dune region in North America, extending over an area of more than 50,000 $\mathrm{km}^{2}$ (Swinehart, 1990; Loope and Swinehart, 2000; Nicholson and Swinehart, 2005), and with sand dunes that reach heights of up to $130 \mathrm{~m}$ (Swinehart, 1990). The contemporary landforms were formed primarily by prevailing NW-SE winds (Ahlbrandt and Fryberger, 1980); today these winds typically exceed the threshold velocity for sand entrainment $\left(5 \mathrm{~m} \mathrm{~s}^{-1}\right)$ about $50 \%$ of the time (Muhs et al., 1997). Effective moisture (precipitation-evapotranspiration) is the key driver of vegetation density, which, in turn, is responsible for the stability of the sand dunes
(Muhs and Maat, 1993). Today, typically during spring and summer, especially between May and July, strong southerly-to-southeasterly winds pass over the Gulf of Mexico, transporting moisture into the central Great Plains (Wilhite and Hubbard, 1998). This growing season moisture sustains dune-stabilizing vegetation. However, in the recent past, extensive drought has reduced the grass cover, resulting in widespread dune migration (Stokes and Swinehart, 1997; Loope and Swinehart, 2000).

A critical component of this landscape that distinguishes it from many other dune fields is the presence of interdunal lakes and wetlands, which together cover an estimated area of more than $700 \mathrm{~km}^{2}$ (Rundquist, 1983). Most of these waterdominated environments are hydrologically connected to the underlying groundwater system of the High Plains Aquifer (Timer, 2003), and their water budget is a manifestation of the height of the local water table. Some lake basins are isolated from the regional groundwater system and respond to climate variation (P-E) more rapidly (Zlotnik et al., 2007). 


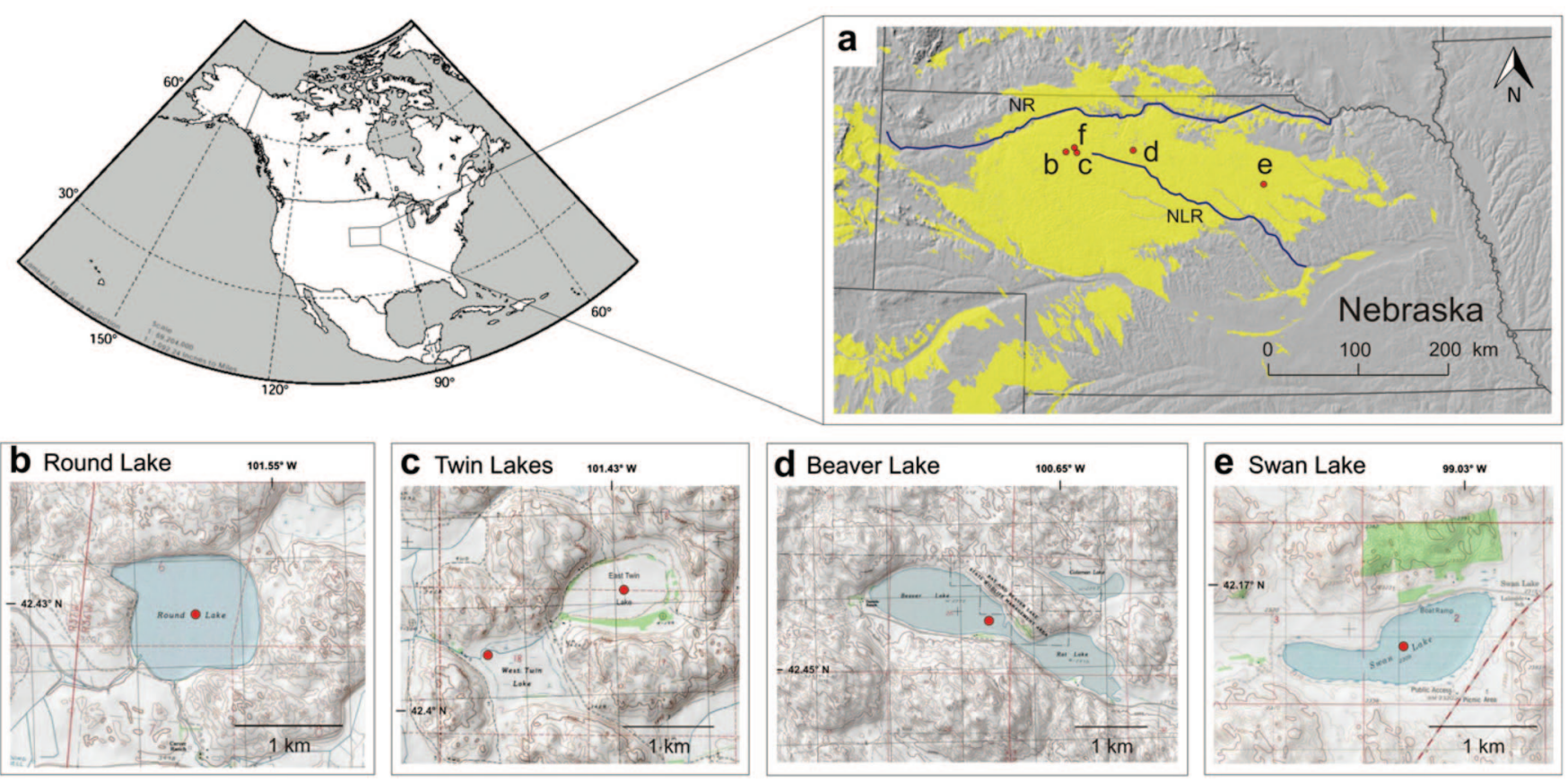

Figure 1. (a) Map of the Nebraska Sand Hills highlighting locations of the four study sites and topographic maps of individual sites (b-e) as well as Jumbo Valley (f). Red circles indicate approximate coring locations. NR = Niobrara River, NLR = North Loup River.

Holocene paleoclimatic evidence from the Nebraska Sand Hills region is predominantly derived from paleosols and eolian sediments (Stokes and Swinehart, 1997; Goble et al., 2004; Miao et al., 2007; Forman et al., 2005), as well as from a limited number of studies of wetland and marsh systems (Mason et al. 1997; Nicholson and Swinehart, 2005). Optically stimulated luminescence (OSL) dating of sand and loess deposits, in conjunction with radiocarbon dates from paleosols interspersed between dune deposits, provides evidence of the timing of droughts that destabilized the dune fields in the past. Results from OSL dating suggest that the Sand Hills of Nebraska experienced a series of recurring and long-lasting droughts over the course of the Holocene (Stokes and Swinehart, 1997; Goble et al., 2004; Miao et al., 2007). A synthesis of the eolian data suggests at least three periods of increased dune activity during the mid and late-Holocene: $3800 \pm 300 \mathrm{a}, 2500 \pm 100 \mathrm{a}$, and $850 \pm 150$ a (Nicholson and Swinehart, 2005; Miao et al., 2007). Yet, high-resolution studies of Holocene dune activity are limited for this region, and as a consequence, it is unclear whether these intervals of major drought were spatially extensive or more localized. Today, the Sand Hills region spans a large precipitation gradient, ranging from about $400 \mathrm{~mm} \mathrm{a}^{-1}$ in the west to more than $600 \mathrm{~mm} \mathrm{a}^{-1}$ in the eastern part (Wilhite and Hubbard, 1998). Whether this gradient was similar in the past is unknown, and it is unclear how climate variation across the region might have influenced dune activity.

Although geomorphic studies have provided an impressive record of regional drought, their temporal resolution is limited, and they only provide a record of landscape destabilization, not of the antecedent conditions that triggered that response. Lake and wetland studies can yield higher temporal resolution and have the potential to provide evidence of the magnitude and duration of the droughts that led to dune activation based on analysis of sedimentology, biota, and/or geochemistry (Fritz, 2008). Diatoms are among the lacustrine proxies that can be used to reconstruct past drought, because of their sensitivity to lake-level and geochemical shifts driven by changes in effective moisture (Stone and Fritz, 2006; Fritz et al., 2010). Lake and wetland sediments also represent another aspect of the broader landscape response to drought that can complement eolian records. Here we present an analysis of diatoms in five late-Holocene lacustrine records spanning an east-west transect across the Nebraska Sand Hills to reconstruct Holocene drought variation at higher temporal resolution than in previous regional studies. In particular, we focus on the following key questions:

1. Are there common intervals of change among the five study sites? If so, do they show similar changes or site-specific responses?

2. How do these lake records compare with other regional records of climate change, particularly the eolian records?

3. How do these records relate to other records from the Great Plains and western U.S., and what does this suggest about environment and climate?

\section{Regional setting}

Central and western Nebraska host a number of small groundwater-fed wetlands and lakes that accumulate peat and lake mud (Steinauer et al., 1996). Lakes and wetlands are especially abundant along ancient channel beds that drained either southeastward into the North Loup River or northeast into the Niobrara River (Figure 1a). All occur in interdunal valleys in between linear or barchanoid dunes, which can reach heights of more than $60 \mathrm{~m}$ in our study area. Topographic relief and the relative location of lakes in the groundwater flow system can have a strong influence on their hydrologic and chemical character (Gosselin et al., 2006). As a result, in Sand Hills lakes, Total Dissolved Solids (TDS) can range from $200 \mathrm{mg} \mathrm{L}^{-1}$ to more than $100,000 \mathrm{mg} \mathrm{L}^{-1}$ (Gosselin, 1997), and alkalinity can vary from $\sim 0$ to more than $90,000 \mathrm{mg} \mathrm{L}^{-1}$ (Schnagl, 1980). Much of this spatial variation in ion chemistry is a product of the relative role of groundwater in the water budget (Zlotnik et al., 2007; Bennett et al., 2007), as well as the age of individual lakes (Gosselin, 1997). 
Table 1. Radiocarbon ages and calibrated age equivalents used in determining age models for Round Lake, Beaver Lake, West Twin, East Twin, and Swan Lake.

\begin{tabular}{|c|c|c|c|c|c|c|c|}
\hline Lab \# & Type & $\begin{array}{l}\text { Depth } \\
\text { (cm) }\end{array}$ & $\begin{array}{l}{ }^{14} \mathrm{C} \text { age } \\
\text { (cal a BP) }\end{array}$ & $\begin{array}{l}\text { Age } \\
\text { error (a) }\end{array}$ & $\begin{array}{l}\text { Cal. range } 2 \\
\text { sigma (cal BP) }\end{array}$ & Median & $\begin{array}{l}\text { Material } \\
\text { (cal BP) }\end{array}$ \\
\hline $\begin{array}{l}\text { Round Lake } \\
\text { CAMS-37942 } \\
\text { CAMS-37933 } \\
\text { CAMS-37934 } \\
\text { CAMS-11303 } \\
\text { CAMS-11570 } \\
\text { CAMS-37931 } \\
\text { CAMS-37935 } \\
\text { CAMS- } 11129\end{array}$ & $\begin{array}{l}\text { AMS } \\
\text { AMS } \\
\text { AMS } \\
\text { AMS } \\
\text { AMS } \\
\text { AMS } \\
\text { AMS } \\
\text { AMS }\end{array}$ & $\begin{array}{l}40 \\
98 \\
108 \\
124 \\
125 \\
137 \\
159 \\
190\end{array}$ & $\begin{array}{l}286 \\
1171 \\
1414 \\
1470 \\
1490 \\
1804 \\
2183 \\
2430\end{array}$ & $\begin{array}{l}51 \\
36 \\
34 \\
85 \\
35 \\
40 \\
35 \\
35\end{array}$ & $\begin{array}{l}343-485 \\
1108-1195 \\
1344-1386 \\
1343-1473 \\
1387-1461 \\
1748-1869 \\
2177-2357 \\
2411-2758\end{array}$ & $\begin{array}{l}428 \\
1160 \\
1369 \\
1421 \\
1431 \\
1821 \\
2285 \\
2619\end{array}$ & $\begin{array}{l}\text { Unidentified seed } \\
\text { Unidentified seed } \\
\text { Unidentified seed } \\
\text { Charcoal } \\
\text { Unidentified seed } \\
\text { Unidentified seed } \\
\text { Unidentified seed } \\
\text { Aquatic plant }\end{array}$ \\
\hline $\begin{array}{l}\text { West Twin Lake } \\
\text { OS-55762 } \\
\text { OS-55693 } \\
\text { OS-55693 } \\
\text { OS-57687 } \\
\text { OS-57512 } \\
\text { OS-55647 }\end{array}$ & $\begin{array}{l}\text { AMS } \\
\text { AMS } \\
\text { AMS } \\
\text { AMS } \\
\text { Conventional } \\
\text { AMS }\end{array}$ & $\begin{array}{l}162.5 \\
221.5 \\
260.5 \\
279.5 \\
349.5 \\
418.5\end{array}$ & $\begin{array}{l}395 \\
805 \\
1540 \\
3180 \\
3210 \\
3760\end{array}$ & $\begin{array}{l}35 \\
45 \\
130 \\
160 \\
40 \\
35\end{array}$ & $\begin{array}{l}426-512 \\
666-795 \\
1227-1733 \\
2962-3730 \\
3359-3487 \\
4069-4237\end{array}$ & $\begin{array}{l}478 \\
743 \\
1531 \\
3423 \\
3436 \\
4170\end{array}$ & $\begin{array}{l}\text { Charcoal } \\
\text { Plant, wood } \\
\text { Plant, wood } \\
\text { Charcoal } \\
\text { Bulk sediment } \\
\text { Plant, wood }\end{array}$ \\
\hline $\begin{array}{l}\text { Beaver Lake } \\
\text { CAMS-18863 } \\
\text { CAMS-18864 } \\
\text { CAMS-42475 } \\
\text { CAMS-18865 } \\
\text { CAMS-42476 } \\
\text { CAMS-18866 } \\
\text { CAMS-42477 } \\
\text { CAMS-42478 }\end{array}$ & $\begin{array}{l}\text { AMS } \\
\text { AMS } \\
\text { AMS } \\
\text { AMS } \\
\text { AMS } \\
\text { AMS } \\
\text { AMS } \\
\text { AMS }\end{array}$ & $\begin{array}{l}401 \\
439.5 \\
485 \\
520.5 \\
553 \\
599.5 \\
651 \\
651\end{array}$ & $\begin{array}{l}1055 \\
1310 \\
1740 \\
3125 \\
3440 \\
3960 \\
4480 \\
4550\end{array}$ & $\begin{array}{l}35 \\
35 \\
50 \\
35 \\
50 \\
35 \\
50 \\
50\end{array}$ & $\begin{array}{l}923-1014 \\
1178-1294 \\
1538-1742 \\
3260-3409 \\
3578-2835 \\
4294-4334 \\
4894-4896 \\
5041-5325\end{array}$ & $\begin{array}{l}964 \\
1248 \\
1652 \\
3355 \\
3704 \\
4430 \\
5145 \\
5174\end{array}$ & $\begin{array}{l}\text { Charcoal } \\
\text { Charcoal } \\
\text { Schoenoplectus seeds, charcoal } \\
\text { Schoenoplectus seeds, charcoal } \\
\text { Sagittaria seeds } \\
\text { Schoenoplectus \& Chenopodium seeds } \\
\text { Schoenoplectus \& Chenopodium seeds } \\
\text { Charcoal }\end{array}$ \\
\hline $\begin{array}{l}\text { Swan Lake } \\
\text { OS-61458 } \\
\text { OS-61851 } \\
\text { OS-60877 } \\
\text { OS-61627 } \\
\text { OS-61010 } \\
\text { OS-72014 }\end{array}$ & $\begin{array}{l}\text { AMS } \\
\text { AMS } \\
\text { AMS } \\
\text { Conventional } \\
\text { AMS } \\
\text { Conventional }\end{array}$ & $\begin{array}{l}66.5 \\
116.5 \\
164.5 \\
218.5 \\
346.5 \\
347.5\end{array}$ & $\begin{array}{l}515 \\
1240 \\
1910 \\
2780 \\
3290 \\
3390\end{array}$ & $\begin{array}{l}123.5 \\
171 \\
60 \\
80 \\
87 \\
35\end{array}$ & $\begin{array}{l}423-670 \\
963-1305 \\
1809-1929 \\
2792-2952 \\
3443-3617 \\
3556-3721\end{array}$ & $\begin{array}{l}571 \\
1168 \\
1881 \\
2888 \\
3547 \\
3655\end{array}$ & $\begin{array}{l}\text { Plant/Wood } \\
\text { Charcoal } \\
\text { Charcoal } \\
\text { Bulk sediment } \\
\text { Plant/Wood } \\
\text { Bulk sediment }\end{array}$ \\
\hline
\end{tabular}

The westernmost of the five study lakes (Figure 1b) is Round Lake (42²5'48" N, 101³3'34" W; elev. 1064 m), which is approximately $2.5 \mathrm{~m}$ deep $\left(z_{\max }\right)$ in the center of the basin (Daniels, 2001), and its shoreline length is about $4.5 \mathrm{~km}$. Alkalinity of $\sim 170 \mathrm{mg} \mathrm{L}^{-1}$ was recorded during the summer of 1957 by McCarraher (1977). Round Lake is situated about $9 \mathrm{~km}$ west of the Twin Lakes (Figure 1c). The Twin Lakes $\left(42^{\circ} 24^{\prime} 30^{\prime \prime} \mathrm{N}\right.$, $101^{\circ} 26^{\prime 2} 20^{\prime \prime} \mathrm{W}$; elev. $\left.1045 \mathrm{~m}\right)$ consist of two small lake basins (each ca $3.5 \mathrm{~km}$ in shoreline length) that are surrounded by large barchanoid dunes. Presently, East Twin is without water due to artificial drainage. Alkalinity measurements were recorded by McCarraher for East Twin Lake $\left(1205 \mathrm{mg} \mathrm{L}^{-1}\right)$ in December of 1959 (McCarraher, 1977). No chemistry data are available from West Twin. Located about $60 \mathrm{~km}$ to the east of the Twin Lakes is Beaver Lake $\left(42^{\circ} 27^{\prime} 35^{\prime \prime}\right.$ N, $100^{\circ} 40^{\prime} 08^{\prime \prime}$ W; elev. $905 \mathrm{~m}$ ) (Figure 1d). It is situated in an interdunal valley within immediate proximity to stabilized linear dunes. Beaver Lake is similar in size to Round Lake and is ca $3.5 \mathrm{~m}$ deep. Swan Lake $\left(42^{\circ} 09^{\prime} 55^{\prime \prime} \mathrm{N}, 9^{\circ} 02^{\prime} 06^{\prime \prime} \mathrm{W}\right.$; elev. $702 \mathrm{~m}$ ) (Figure 1e) is about $140 \mathrm{~km}$ to the east of Beaver Lake, near the eastern boundary of the Sand Hills. Dunes in the eastern part of the Sand Hills are smaller overall, and the relief is generally not greater than $40 \mathrm{~m}$. Swan Lake has a maximum depth of $\sim 3.5 \mathrm{~m}$. With a shoreline length of $\sim 5 \mathrm{~km}$, it represents the largest lake among the five study sites. The lakes in this study are without surface inflow or outflow (topographically closed), although Bea- ver Lake is hydrologically connected to Rat Lake to the east, which in turn has no surface outlet (Figure 1).

In most Sand Hill lakes, the combination of strong winds and shallow depth do not promote conditions for seasonal stratification, and most lakes are isothermal, regardless of season (La Baugh, 1986). Usually, the 1\% level of surface light does not penetrate to the bottom in Sand Hill lakes deeper than $\sim 1 \mathrm{~m}$, because of the high turbidity. Secchi disk transparency, a common method to measure water clarity, is commonly less than $55 \mathrm{~cm}$, because of the shallow water depths and strong winds, which keep particulate matter suspended in the water column. Recent studies of lakes in the Sand Hills region suggest considerable seasonal and spatial variation in nutrient limitation, conductivity, and alkalinity (Salm et al., 2009).

\section{Materials and methods}

\subsection{Field}

Round Lake was cored from a raft during the summer of 1999. A $230 \mathrm{~cm}$ Nesje piston core $(7.2 \mathrm{~cm}$ diameter) and a $25 \mathrm{~cm}$ Glew core $(6.3 \mathrm{~cm}$ diameter) were retrieved from near the center of Round Lake within $2 \mathrm{~m}$ of each other. Beaver Lake was cored in July 1995 with a Livingstone-Wright square-rod piston corer $(5 \mathrm{~cm}$ diameter) at the deepest part 
Table 2. Field and laboratory data, as well as OSL results, from three sites: 1) UNL 1595-1596: sand dune at Tom Hansen Ranch north of the Platte River; 2) UNL 1597-1600: sand dune north of East Twin Lake; 3) UNL 2194, 2198, 2202: sand intervals of Swan Lake core.

\begin{tabular}{|c|c|c|c|c|c|c|c|c|c|c|}
\hline Sample \# & $\begin{array}{l}\text { Depth } \\
(\mathrm{cm})\end{array}$ & $\begin{array}{l}\text { In situ moisture } \\
\text { content (\%) }\end{array}$ & $\begin{array}{l}\mathrm{K}_{2} \mathrm{O} \\
(\%) \\
\end{array}$ & $\begin{array}{l}\text { Th } \\
(\mathrm{ppm})\end{array}$ & $\begin{array}{l}U \\
(\mathrm{ppm})\end{array}$ & $\begin{array}{l}D_{\text {cosmic }} \\
\left(\text { Gy } \mathrm{a}^{1} \times 10^{3}\right)\end{array}$ & $\begin{array}{l}\mathrm{D}_{\text {Total }} \\
\left(\text { Gy } \mathrm{a}^{1} \times 10^{3}\right)\end{array}$ & $\begin{array}{l}\mathrm{De}_{\mathrm{e}} \\
\left(\mathrm{Gy} \pm 1 \sigma_{\mathrm{s}}\right)\end{array}$ & $\begin{array}{l}\text { Aliquots } \\
\text { (n) }\end{array}$ & $\begin{array}{l}\text { Age } \\
(a \pm 1 \sigma)\end{array}$ \\
\hline UNL 1595 & 120 & 0.61 & 1.5 & 3.9 & 0.7 & 0.1983 & $1.97 \pm 0.08$ & $1.23 \pm 0.04$ & 18 & $628 \pm 37$ \\
\hline UNL 1596 & 607 & 8.74 & 1.63 & 4.3 & 0.8 & 0.0976 & $2.02 \pm 0.08$ & $5.37 \pm 0.08$ & 20 & $2664 \pm 142$ \\
\hline UNL 1598 & 320 & 8.07 & 1.28 & 5.1 & 0.8 & 0.1530 & $1.82 \pm 0.08$ & $1.43 \pm 0.08$ & 13 & $788 \pm 61$ \\
\hline UNL 1599 & 470 & 0.29 & 1.32 & 4.5 & 1 & 0.1298 & $1.88 \pm 0.08$ & $1.60 \pm 0.03$ & 16 & $853 \pm 46$ \\
\hline UNL 1600 & 670 & 3.97 & 1.33 & 4.5 & 1 & 0.1053 & $1.90 \pm 0.08$ & $1.65 \pm 0.04$ & 16 & $868 \pm 47$ \\
\hline UNL 2194 & 250 & 25 & 2.01 & 3.64 & 0.73 & 0.1221 & $1.73 \pm 0.09$ & $5.90 \pm 0.10$ & 20 & $3411 \pm 217$ \\
\hline
\end{tabular}

of the basin. Sediment cores from West Twin (1999) and East Twin (2006), as well as Swan Lake (2007), were obtained by vibracoring (Last and Smol, 2001). The vibracore of West Twin Lake was taken from the edge of the lake basin, while the cores from East Twin Lake and Swan Lake were taken from the center of the lakes.

\subsection{Chronology}

In most cases, the chronology for the cores is based on linear interpolation of accelerator mass spectrometry (AMS) radiocarbon dates of terrestrial charcoal, seeds, plant fragments, and bulk sediment (Table 1). All AMS dates were calibrated to calendar years BP using CALIB 5.0.1 (Stuiver and Reimer, 1993) and are presented with two sigma error ranges.

The top $30 \mathrm{~cm}$ of the Round Lake core was sampled in $5 \mathrm{~cm}$ increments for ${ }^{210} \mathrm{~Pb}$ dating. Prior to analysis, samples were dried and homogenized. The dates were obtained by using the Constant Rate of Supply (CRS) model (Appleby, 2001) on the activity data (Daniels, 2001).

In addition, we sampled a stratigraphic section of the dune field immediately north of East Twin Lake for OSL dating, using 90-150 $\mu \mathrm{m}$ quartz grains under the Single Aliquot Regenerative protocol (Murray and Wintle, 2000). A second vibracore was obtained from Swan Lake at approximately the same location as the primary core in order to date two conspicuous sand layers within the core (Table 2). The OSL ages from the lake sediment core were integrated in constructing the chronology of Swan Lake.

\subsection{Diatoms}

Diatom analyses at decadal to multi-decadal resolution were carried out from lake sediments of all five sites. All cores were sampled for diatoms in 1-4 cm intervals, and diatom samples were prepared according to standard techniques (Battarbee, 1986). At least 300 diatom valves from each interval were counted in transects under oil immersion on a Zeiss Axioscop 2 plus microscope with a 100x objective. Primary taxonomic references used for all lakes were Patrick and Reimer (1966, 1975) and Krammer and Lange-Bertalot (1986, 1988, 1991a, 1991b).

\subsection{Multivariate numerical analyses}

In order to compare the five records, we developed diatom zonation schemes at each site on the basis of stratigraphically constrained cluster analysis. The software PSIMPOLL 4.10 (Bennett, 2002) was used, which applies an incremental sum of squares (CONISS) algorithm and, in conjunction with a broken-stick model, demarcates significant zones. Species with relative abundance $>2 \%$ were used, and data were square-root transformed prior to analysis so that the data approximated a normal distribution pattern. The resultant dissimilarity coefficient is chord distance.

A transfer function generated from modern diatom samples and depth data from 69 lakes across Nebraska (Shinneman et al., 2010) was applied to generate diatom-inferred water depth reconstructions for each site. Quantitative inferences of depth in these lakes are complicated by high seasonal variability and by the inter-relationship of depth and multiple other variables that affect diatoms, particularly light and nutrient concentrations. None-the-less water depth showed significant independent explanatory power $\left(r^{2}=0.83, r_{\text {boot }}^{2}=0.61\right)$ in terms of diatom distribution when the measured lakedepths were compared to diatom-inferred depths. The predictive power of this model was assessed using a weighted-averaging approach with classical de-shrinking and bootstrap error estimation in C2 software (version 1.4; Juggins, 2003). The strength of each model was evaluated using the crossvalidated coefficient of determination $\left(r^{2}\right)$ and the root mean square error $(\mathrm{RMSE}=0.13 \log$ (meters)). A validation step of bootstrapping with 1000 cycles was used to generate a bootstrapped coefficient of determination $\left(r^{2}{ }_{\text {boot }}\right)$ and a root mean square error of prediction (RMSEP $=0.31$ log (meters)), which more realistically portrayed error estimates (Fritz et al., 2010). Prior to analysis, depth measurements were log-transformed to ensure normal distribution of the data.

Z-scores or normalized scores were calculated from lakedepth reconstructions of each lake basin from equally-spaced time intervals (20 a) to aid in the identification and interpretation of regional versus local drought episodes across the sites. The formula for the $z$-score calculation is based on: $z=(x-\mu) / \sigma$, where $x=$ raw score, $\mu=$ mean of the population and $\sigma=$ standard deviation of the population.

A spectral analysis using the multi-taper method (MTM) (Mann and Lees, 1996) was performed on individual diatom species, groups of species, and diatom indices in order to identify significant frequencies of variation in each of the lake sites. Prior to spectral analysis, records were re-sampled to create uniformly spaced time series and normalized to unit variance using the program Analyseries (Paillard et al., 1996).

\subsection{Grain-size and sand concentration}

A grain-size analysis was performed on $0.5 \mathrm{~g}$ of wet sediment at $2 \mathrm{~cm}$ intervals on the Beaver Lake core using a Coulter Laser Diffraction unit. If present, secondary carbonates were removed with a $10 \% \mathrm{HCl}$ solution. Organic matter was removed by adding $3 \mathrm{ml}$ of concentrated hydrogen peroxide $(30 \%)$ to each sample. $10 \mathrm{ml}$ of $1 \mathrm{M} \mathrm{NaOH}$ were added for the removal of biogenic silica. The sand samples were then separated into five different size fractions (D10, D25, D50, D75, and D90). From these five size fractions, we calculated the mean grain-size and compared it with other proxies. For the Swan Lake and East Twin records, sand concentrations (expressed 

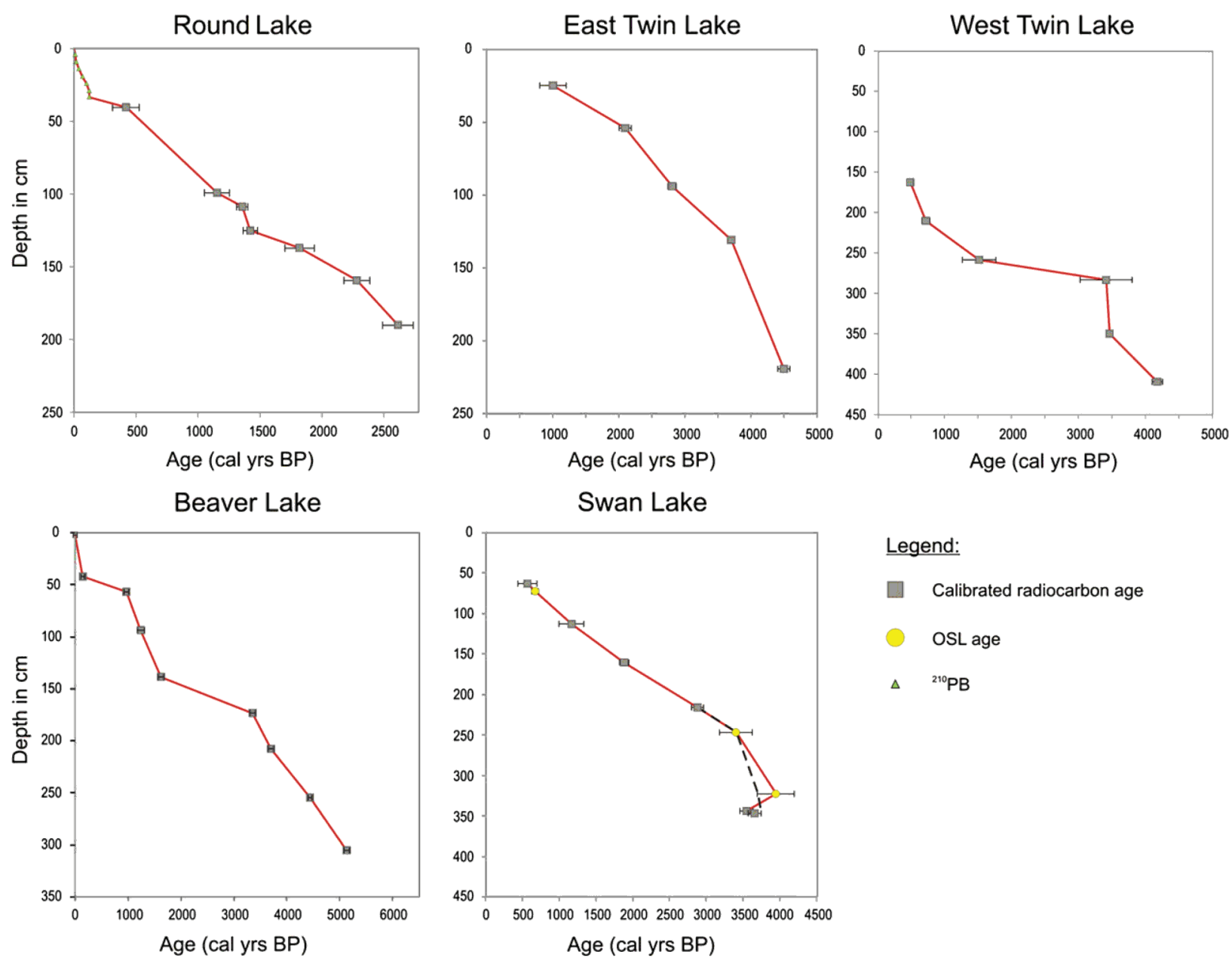

Legend:

$\square$ Calibrated radiocarbon age

OSL age

$\triangle \quad{ }^{210} \mathrm{~PB}$

Figure 2. Age-depth models of all lakes derived from linear interpolation between calibrated ${ }^{14} \mathrm{C}$, OSL, and ${ }^{210} \mathrm{~Pb}$ ages (see Table 1). Calibrated radiocarbon ages are based on AMS dates of terrestrial grass charcoal and seeds and error bars represent 2 sigma. The dotted line in the Swan Lake age model represents the best correlation fit between the oldest OSL and carbon dates.

in $\%$ dry weight) were measured in $4 \mathrm{~cm}$ increments. Samples were treated with $\mathrm{HCl}$ (hydrochloric acid) and $\mathrm{H}_{3} \mathrm{PO}_{4}$ (phosphoric acid) to remove carbonates and organic matter, respectively. Diatom frustules were subsequently removed by wet sieving through a $0.062 \mathrm{~mm}$ sieve and treating the remaining sand fraction with $3 \% \mathrm{HF}$ for $1 \mathrm{~min}$. The samples were then decanted, washed three times, and finally dried.

\section{Results and discussion}

\subsection{Chronology}

Age models suggest that Round Lake and East Twin Lake have relatively simple depositional histories with continuous sedimentation (Figure 2). Beaver Lake and West Twin Lake, in contrast, had relatively slow depositional rates between 3300 and $1500 \mathrm{cal}$ a BP. A similar break in sedimentation ( 2900-1700 cal a BP) was reported from wetland records of the nearby Jumbo Valley (Figure 1f) and was attributed to a decrease of organic matter accumulation caused by drier climate or removal of peat by fire (Nicholson and Swinehart, 2005). The age of the lower section in the Swan Lake record, particularly the thick sand deposit, is uncertain, because of three conflicting ages. The midpoint of the lower OSL age deviates by more than a hundred years from the two radiocarbon ages below, making a linear interpolation between these ages impossible. However, the large age errors inherent in the OSL date allows for the correlation of its lowest age with the oldest age range of the radiocarbon date below (Figure 2). This age model represents a better fit in terms of simultaneous changes in diatom stratigraphy when Swan Lake is compared with the other lakes.

\subsection{Paleolimnology of individual sites}

The diatom records of all five Sand Hills lakes are broadly similar in terms of community structure and dominant taxa. Benthic (near-shore, shallow water) diatom assemblages are generally dominated by Nitzschia spp. (Nitzschia amphibia, Nitzschia palea, Nitzschia frustulum), Gomphonema spp., Navicula spp., Fragilaria capucina sensu lato, and Fragilaria tenera. Tychoplankton include Pseudostaurosira brevistriata, Staurosira construens sensu lato, and Staurosirella pinnata sensu lato. These are small benthic Fragilariaceae that form chains and are circumstantially carried into the plankton by turbulence. Because shallow Sand Hills lakes are exposed to strong winds year-round, small chain-forming diatoms are frequently entrained in the water column. In all lakes, the planktic (deeper open-water) flora is dominated by either Aulacoseira ambigua or small Stephanodiscus spp. (Stephanodiscus minutulus, Stephanodiscus parous, Stephanodiscus hantzschii). Other significant planktic diatoms include Aulacoseira distans, Aulacoseira granulata, Stephanodiscus niagarae, and Cyclostephanos dubius. 


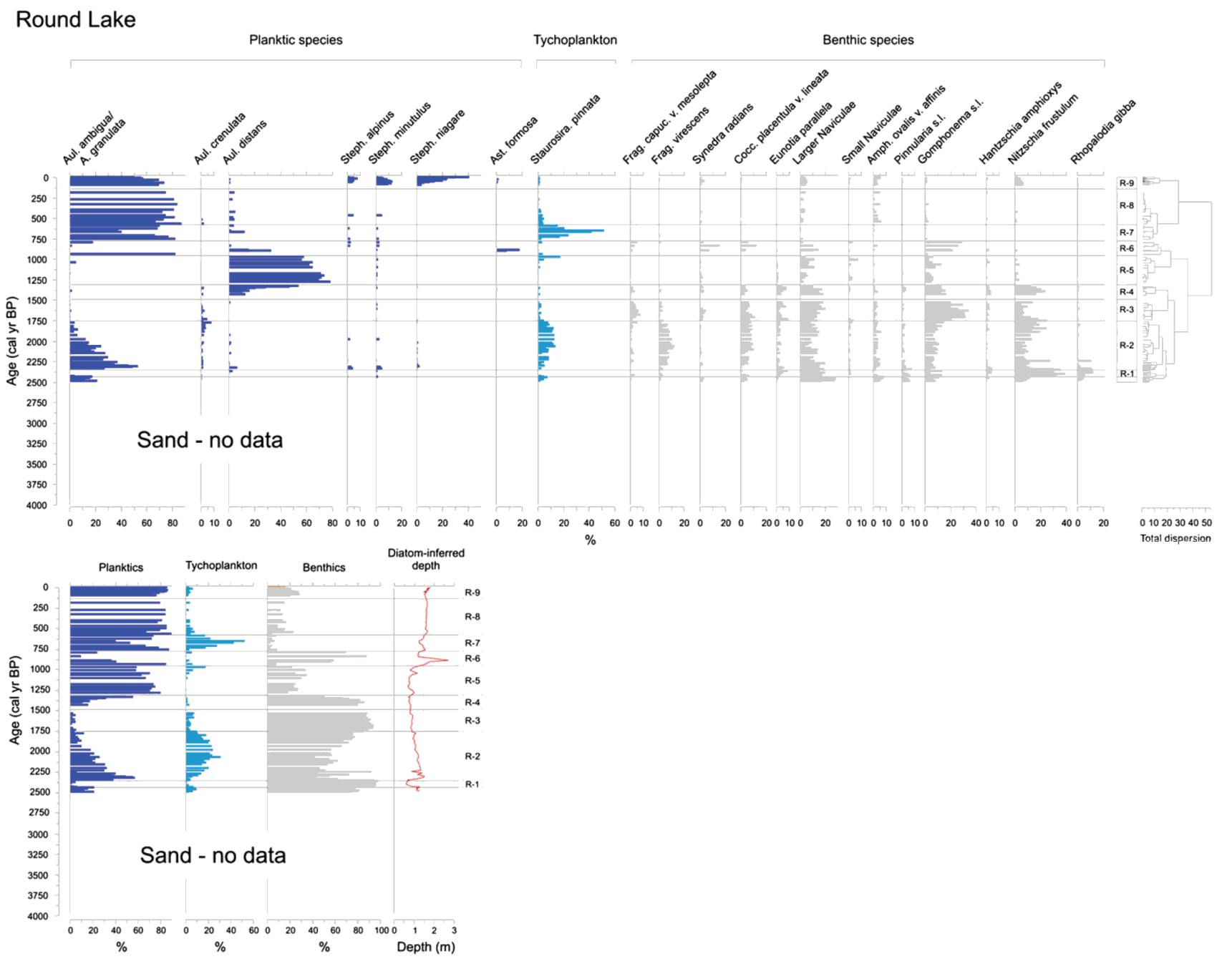

Figure 3. Top - Round Lake diatom stratigraphy and diatom-based zonations plotted against time (cal a BP). Zonations are based on CONISS algorithm with significant clusters identified by the broken-stick method. The $x$-axis represents percent abundance, the $y$-axis age is calibrated years BP. Bottom - Diatom summaries of the relative abundance of planktic, benthic, and tychoplanktic species and the diatom-inferred lake-level reconstruction.

\subsection{Round Lake}

Unstructured sands characterize the base of the Round Lake core $(2800-2300 \mathrm{cal}$ a BP). The sands are thought to be related to deposition of a dune blockage of the paleovalley, which led to the formation of Round Lake. Similar scenarios of dunes blocking ancient riverbeds have been documented in the western Sand Hills (Loope et al., 1995).

The diatom record (Figure 3), just below the first zone (2500$2400 \mathrm{cal} \mathrm{a} \mathrm{BP})$, is characterized by the presence of $\sim 20 \%$ planktic A. ambigua/granulata and a significant abundance (>25\%) of benthic Naviculoid species, suggesting a sudden rise in lakelevel following formation of the basin by dune blockage. Zone $\mathrm{R}-1$, in turn, is largely characterized by periphytic (attached to plants) species, including N. frustulum, Gomphonema spp., and Navicula spp. and the loss of virtually all plankton, attesting to shallower water conditions between $\sim 2500-2300 \mathrm{cal}$ a BP. $N$. frustulum has a wide salinity tolerance $\left(0.35-620 \mathrm{~g} \mathrm{~L}^{-1}\right)$ (Wilson et al., 1996). Elevated abundances of this species were found in surface-samples from Sand Hills lakes that have high conductivities and alkalinities (Shinneman et al., 2010). This suggests that in this interval, Round Lake was considerably more alkaline than in recent times.
A sharp increase of A. ambigua/ A. granulata in Zone R-2, at around $2300 \mathrm{cal}$ a BP, and a concomitant decline of $N$. frustulum and $R$. gibba, marks a brief increase in lake-level and effective moisture that lasted about half a century (2300-2250 cal a BP). Both $A$. ambigua and $A$. granulata are common planktic species and often occur during turbulent mixing (Anderson, 2000), when light availability is low and Si:P ratio is high. Both species are characteristic of eutrophic to mesotrophic temperate lakes (Brugam and Speziale, 1983). Benthic diatoms subsequently dominate the system during zone R-3 (2250-1350 cal a $\mathrm{BP})$, suggesting a return to low lake-levels and low effective moisture. A diatom-inferred lake-level reconstruction suggests particularly low stands between $\sim 1500$ and 1300 cal a BP (Figure 3), and OSL ages of dunes adjacent to Round Lake and nearby Cottonwood Lake also suggest dune activity as a result of drought conditions, centering around $1390 \pm 130$ a (Forman et al., 2005).

Zones R-4 and R-5 (1350-900 cal a BP, Figure 3) are characterized by the dominance of $A$. distans ( $~ 60 \%$ of the assemblage) and a reduction in N. frustulum and other common benthic diatoms. A. distans is a bog and wetland species (Brugam and Swain, 2000), which typically occurs in low alkalinity systems (19-32 meq L ${ }^{-1}$, Davis et al., 1994). In this context higher 


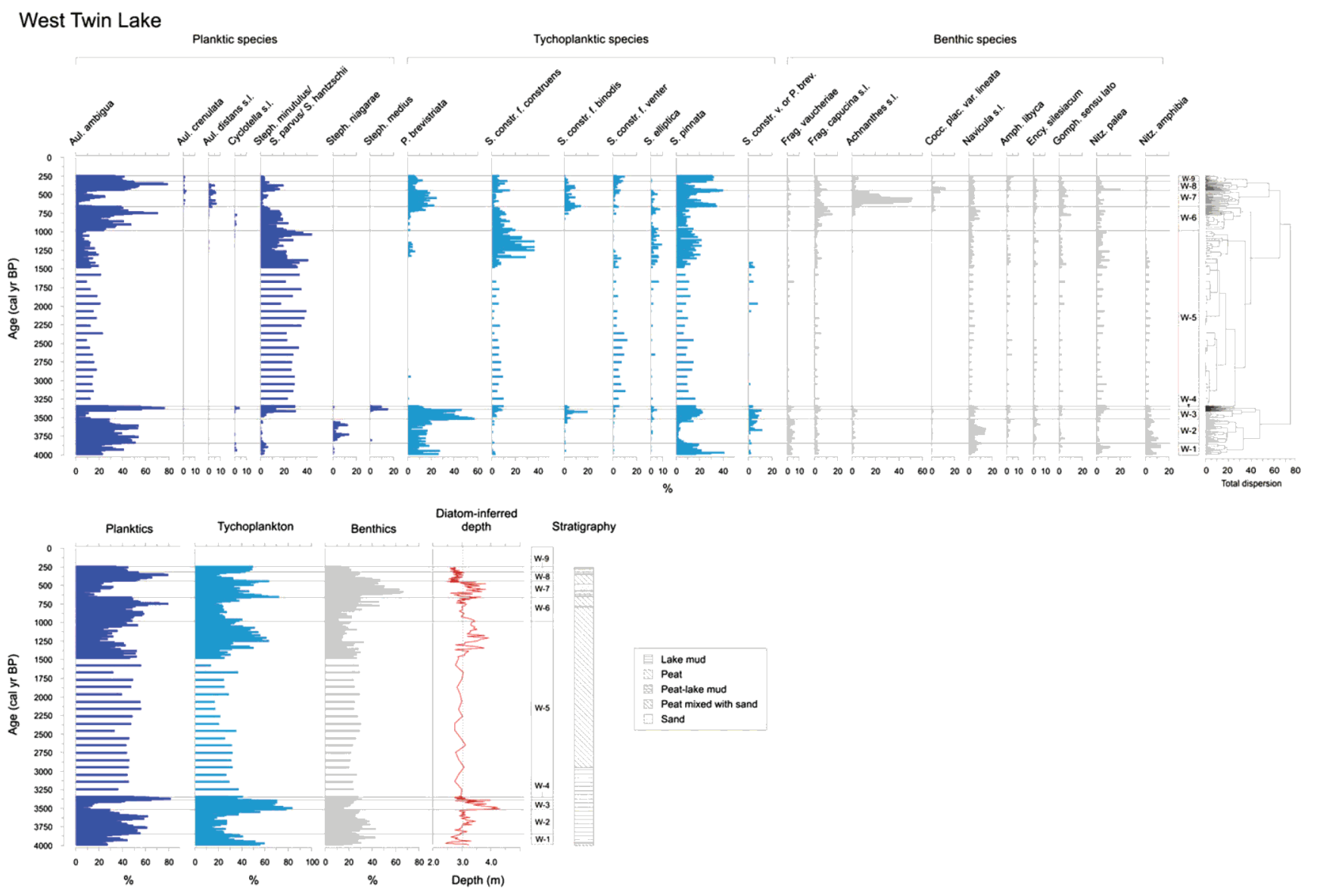

Figure 4. Top - Diatom stratigraphy of West Twin Lake including diatom-based zonations plotted against time (cal a BP). Bottom - Diatom summaries compared to the diatom-inferred lake-level curve and a simplified core stratigraphy.

abundances probably represent episodes of lake-level decline and alkalinity values considerably lower than those in recent decades, as a result of reduced groundwater input. The taxon was not found in any of the 69 lake surface-sediment samples that make up our training set, but we equate high abundances with lowered lake-levels that produced a wetland, similar to the fens that are common in the Sand Hills region nearby. This species also occurs in West Twin Lake and Swan Lake between ca1250-400 cal a BP (see below), albeit with lower percentages compared with Round Lake.

The diatom stratigraphy of zones R-6 through R-9 suggests generally higher lake-level (900 cal a BP - present). A brief lake-level rise occurred during the first half of zone R-6, between 950 and $880 \mathrm{cal}$ a BP, as indicated by the replacement of A. distans by $A$. ambigua and A. formosa. The diatom-inferred lake-level reconstruction suggests a relatively quick increase to an unprecedented high-stand, followed by a short low lake stand until around $770 \mathrm{cal}$ a BP. This interval is known for its eolian activity throughout the Sand Hills region (Nicholson and Swinehart, 2005; Miao et al., 2007) and coincides with the Medieval Climate Anomaly (MCA), a period of widespread hydrological anomalies throughout western North America (Sridhar et al., 2006). The last 770 years of the Round Lake record is dominated by A. ambigua/A. granulata and suggests a return to relatively high lake-levels and higher effective moisture. This overall stable period is interrupted by a single brief drought episode at $\sim 700 \mathrm{cal}$ a BP, based on a short spike of small tychoplankton. This corresponds with eolian activity recorded in dunes adjacent to Round Lake and Cottonwood Lake (Forman et al., 2005). No evidence was found in the di- atom record to suggest drought conditions at $470 \pm 40$ a as reported by Forman et al. (2005).

\subsection{Twin Lakes}

The records of these two lakes are similar with respect to the major changes in species composition, in particular the coincident occurrence of $S$. niagarae at the base of the sequence, the rise of small Stephanodiscus spp. $\sim 3300 \mathrm{cal}$ a BP, the dominance of Aulacoseira spp. and Stephanodiscus spp. from 3300 to $650 \mathrm{cal}$ a BP, and the increase of Achnanthes spp. at around $650 \mathrm{cal} \mathrm{a}$ $\mathrm{BP}$ (Figure 4 and Figure 5). However, the fluctuations in diatom abundance differ in magnitude between the two lakes, and a few intervals show divergent signals. These discrepancies are likely a manifestation of coring location in relation to shoreline proximity. The West Twin Lake vibracore was obtained from the edge of the lake, while East Twin Lake was cored at the lake center. Therefore, the diatom community of West Twin Lake consistently shows a stronger benthic signature and is less variable than the East Twin Lake core from the lake center.

According to the diatom-inferred depth reconstruction (Figures 4 \& 5), lake-level was relatively low in both lakes between 4000 and $3800 \mathrm{cal}$ a BP (zones W-1 \& E-1), as suggested by the large populations of small tychoplanktic alkaliphilic Fragilariaceae, which have relatively shallow depth optima in the calibration set. These taxa have been found in a wide range of environments (Westover et al., 2005), but the most important factors controlling their distribution may be light and tolerance of physical disturbance (Anderson, 2000). A rise in 


\section{East Twin Lake}

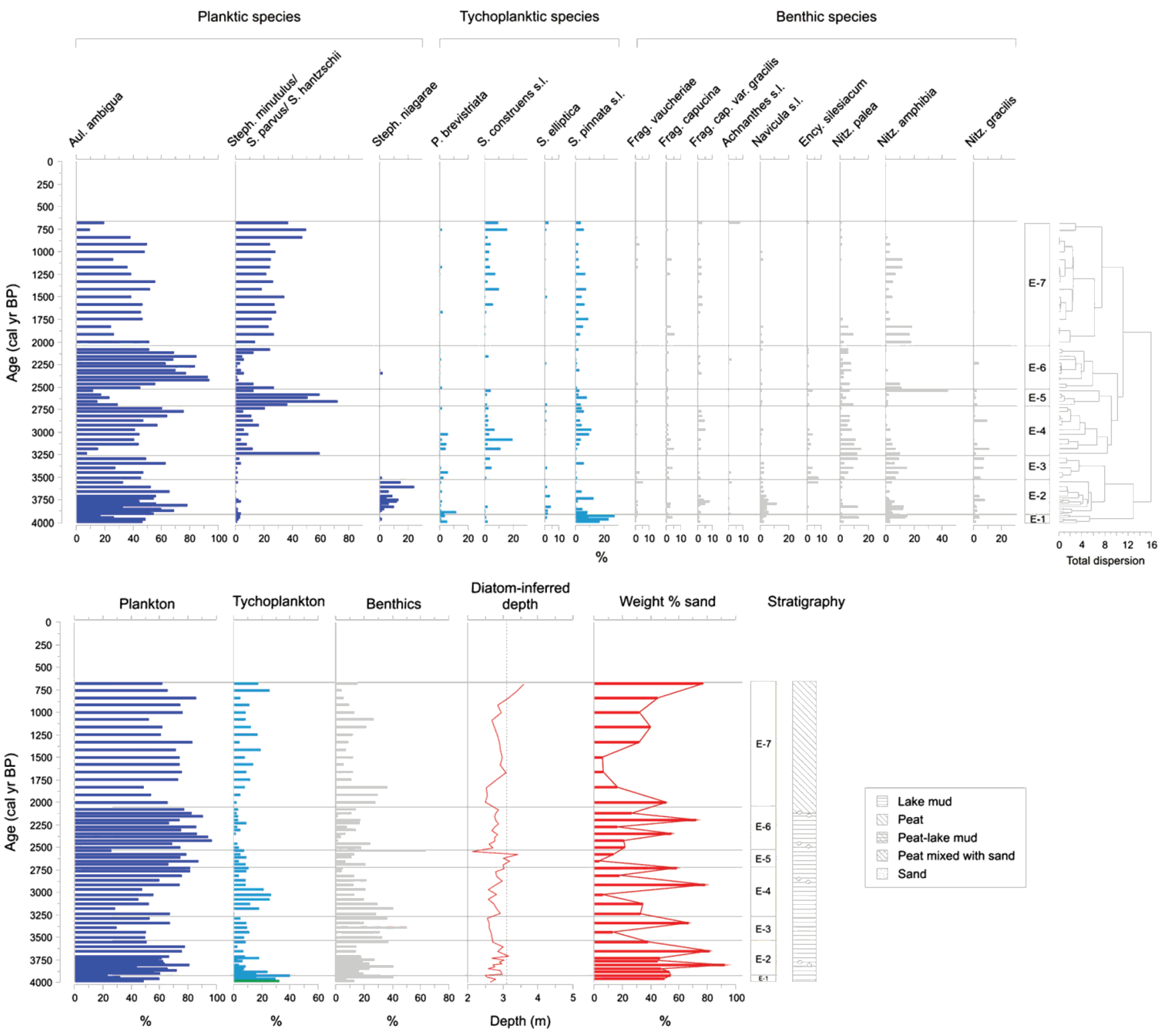

Figure 5. Top - East Twin Lake diatom stratigraphy and diatom-based zonations plotted against time (cal a BP). Bottom - Comparison of plankton, tychoplankton, and benthic summaries with the diatom-inferred lake-level curve, weight \% sand, and core stratigraphy.

A. ambigua and S. niagarae, planktic taxa with moderate depth optima, and a concomitant decrease in tychoplankton, suggest rising lake-levels between 3800 and 3500 cal a BP (zones W-2 \& E-2). S. niagarae is a common planktonic species in eutrophic lakes in the northern United States and Canada (Theriot and Stoermer, 1981; Theriot, 1987; Håkansson and Kling, 1989), including in eutrophic prairie lakes in Minnesota (Brugam and Speziale, 1983).

Large increases in tychoplankton (zone W-3) and benthic $N$. palea and N. amphibia (zone E-3) indicate falling lake-levels between 3500 and 3300 . The following period (3300-1250 cal a BP) is generally characterized by moderately high lake-levels, as indicated by dominance of A. ambigua and small Stephanodiscus spp. Modern ecological data from surface-sample calibrations indicate that the small Stephanodiscus spp. (S. minutulus, S. parvus, and S. hantzschii) are planktic taxa that are characteristic of high phosphorus concentrations (Bradbury, 1988; Cumming et al., 1995; Reavie et al., 1995) and moderate to high lake-levels in the Nebraska calibration set (Shinneman et al., 2010). This overall period of moderately high lake-levels is interrupted by two dry intervals $(\sim 2500$ and $\sim 1900 \mathrm{cal}$ a BP) with high abundances of N. amphibia, a diatom with very shallow depth optima in modern samples. This inferred dry interval overlaps with the interval of slow sedimentation (Figure 2) observed in the core. Between $\sim 1250$ and $1000 \mathrm{cal}$ a BP, diatom assemblages indicate modest lake-level decline evident in the increase in tychoplanktic species at West Twin Lake and to a lesser degree in East Twin Lake.

Between 1000 and 700 cal a BP (zone W-6), increasing numbers of A. ambigua in the littoral core from West Twin Lake suggest low-light conditions, possibly associated with greater 


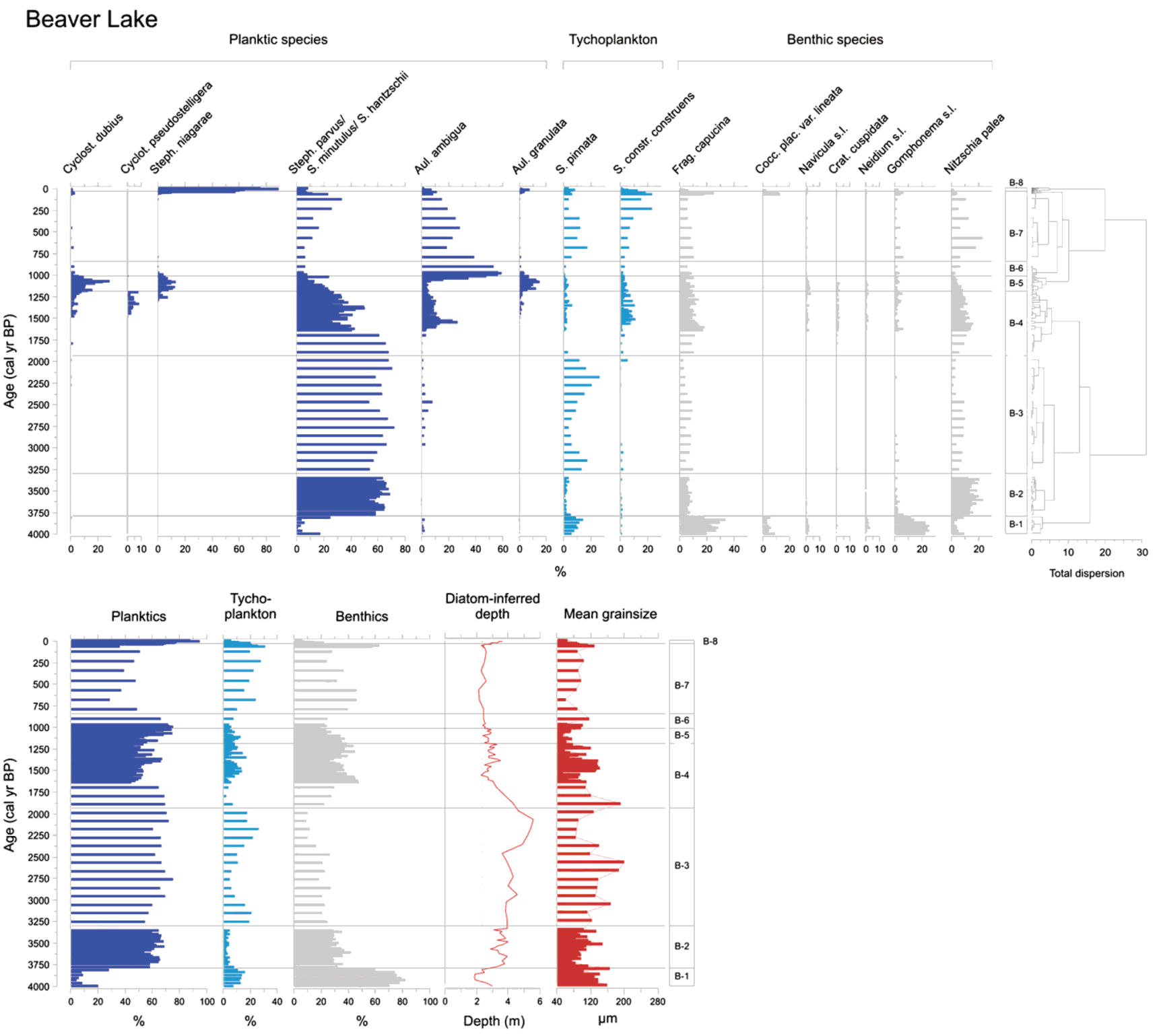

Figure 6. Top - Diatom stratigraphy and diatom-based zonations plotted against time (cal a BP) for Beaver Lake. Bottom - Comparison of plankton, tychoplankton, and benthic distributions with the diatom-inferred lake-level curve and grain-size.

mixing by wind and likely increased sand influx. In the central core from East Twin Lake, A. ambigua also increases around this time while benthic diatoms, such as N. amphibia decline. The decline in benthic diatoms produces an inferred lake-level increase (Figures 4 \& 5), but it is also possible that this decline is driven by either decreased light for benthic species and/or reduced littoral benthic habitat, rather than a true lake-level increase. The interval between $\sim 1000$ and 700 cal a BP coincides with the MCA and the extensive regional drought that has been reported from many sites in the Nebraska Sand Hills (Miao et al., 2007). Four OSL dates obtained from the top $7 \mathrm{~m}$ of the sand dune immediately northwest of East Twin Lake ranged between 900 and $720 \mathrm{cal}$ a BP, demonstrating local eolian activity during this period (Table 2). Moreover, weight \% sand concentrations from both East Twin Lake and the neighboring Jumbo Valley site (Nicholson and Swinehart, 2005) reveal increased sand influx (Figure 5). Thus, there is consider- able evidence for eolian activity as a result of a lowered local water table caused by extensive drought.

Most of the uppermost record is absent in East Twin Lake but in West Twin Lake, the period between 700 and $400 \mathrm{cal} \mathrm{a}$ $\mathrm{BP}$ (zone W-7) is characterized by a distinctive increase of tychoplanktic Pseudostaurosira and of epiphytic Achnanthes spp., suggesting continued low lake-levels and dry conditions. The diatom-inferred depth reconstruction, in contrast, indicates highly fluctuating lake-levels during this period. Aside from the increase in tychoplankton, which does not clearly reflect the direction of lake-level fluctuations in our data set, the abrupt increase of the epibenthic genus Achnanthes to more than $25 \%$ of the entire population does suggest more plant growth and most likely shallower water during most of this interval. Zones W-8 and W-9 (400-250 cal a BP) suggest a return to wetter conditions as evidenced by a spike in the planktic diatom $A$. ambigua. 


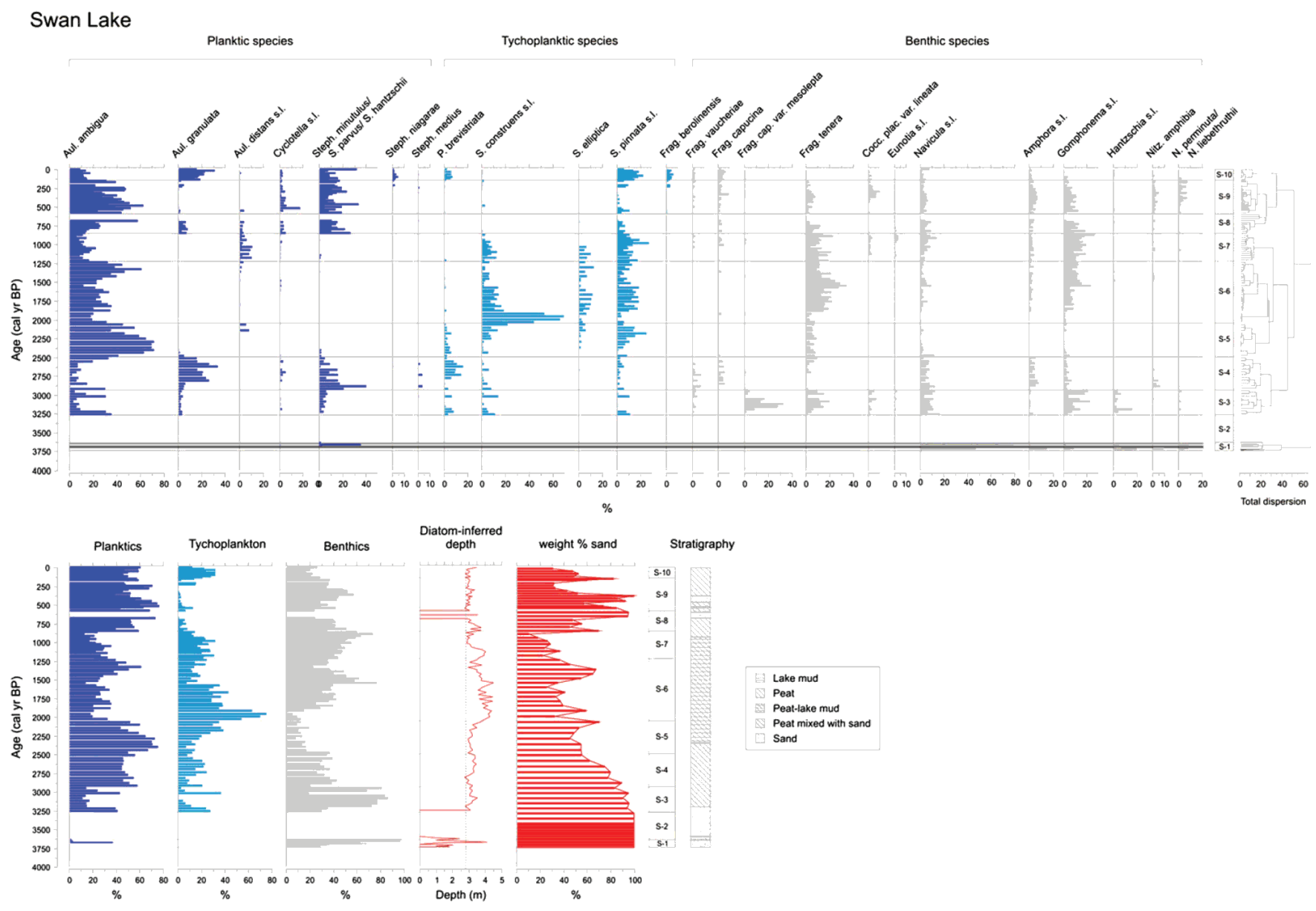

Figure 7. Top - Swan Lake diatom stratigraphy and diatom-based zonations plotted against time (cal a BP). Bottom - Comparison of plankton, tychoplankton, and benthic summaries with the diatom-inferred lake-level curve, weight \% sand, and core stratigraphy.

\subsection{Beaver Lake}

High abundances of benthic Gomphonema spp. (averaging $\sim 20 \%$ ) and F. capucina (averaging $\sim 30 \%$ ), combined with relatively high sand influx, suggest dry conditions and low lakestands during B-1 between 3950 and $3800 \mathrm{cal}$ a BP (Figure 6). A dramatic reorganization in the diatom flora occurs at around $3800 \mathrm{cal}$ a BP, evidenced by a sudden increase of planktic diatoms. Dominance of planktic small Stephanodiscus species persists for the following 2000 years, suggesting high lake-levels.

Lake-levels gradually fall to intermediate depths during most of B-4 and B-5 between 1800 and 1000 cal a BP, as indicated by decreasing abundances of Stephanodiscus spp., a simultaneous recurrence of Fragilariaceae and other benthic species, and elevated abundances of A. ambigua. The initial drop in lake-level corresponds with changes in sedimentation rate observed in the age-depth profiles (Figure 2).

During Medieval times ( 1000-800 cal a BP, zone B6) the dominance of $A$. ambigua indicates moderately shallow conditions and extensive wind-driven mixing, and an increase in sand size at $\sim 900 \mathrm{cal}$ a BP is consistent with the hypothesis of local eolian activity caused by drought. The subsequent increased abundance of Fragilariaceae and Nitzschia spp. (zone B-7) suggest a reduction in lake-levels and possibly a higher abundance of aquatic macrophytes. The most recent $\sim 130$ years of the record are characterized by a rise of $S$. niagarae, which may be related to anthropogenically induced nutrient enrichment associated with agricultural expansion in the region.

\subsection{Swan Lake}

The bottom $15 \mathrm{~cm}$ of the Swan Lake vibracore consists of sandrich peat. Above sit dune-derived sands with a few thin organic laminae. These deposits of zones S-1 and S-2, which are more than $90 \mathrm{~cm}$ thick and represent 450 years in time (3710$3260 \mathrm{cal}$ a BP), provide unequivocal evidence for eolian activity related to drought. Diatoms were found only in two organic layers of S-1 at $\sim 3650 \mathrm{cal}$ a BP and consisted mainly of benthic Naviculoids. Examination of the diatom assemblage and weight \% sand profile (Figure 7) above the sand unit (zone S-3) indicate that dry conditions prevailed for the following $\sim 300$ years, although water availability increased, and the lake was established during this time. This interval ( $3250-$ $2900 \mathrm{cal}$ a BP) is characterized by the only significant occurrences of F. capucina var. mesolepta and Hantzschia amphioxys. The former is alkaliphilous and mainly occurs at relatively high pH (>7) (Krammer and Lange-Bertalot, 1988), while the epipelic $H$. amphioxys often extends into the subaerial habitats of soils (Round et al., 1990). The occurrences of these species suggest very shallow conditions or perhaps an ephemeral wetland. Lake-levels became consistently higher and, by $2900 \mathrm{cal}$ a $\mathrm{BP}$, the diatom community reflects deeper conditions with plankton averaging nearly 50\% (zone S-4). At $\sim 2500 \mathrm{cal} \mathrm{a} \mathrm{BP,}$ sand concentrations decreased to about $50 \%$ and continued to decline until about $1600 \mathrm{cal}$ a BP. During this time (zone S-5), abundances of A. granulata, S. minutulus and benthic diatoms dropped significantly. The planktic community, averag- 


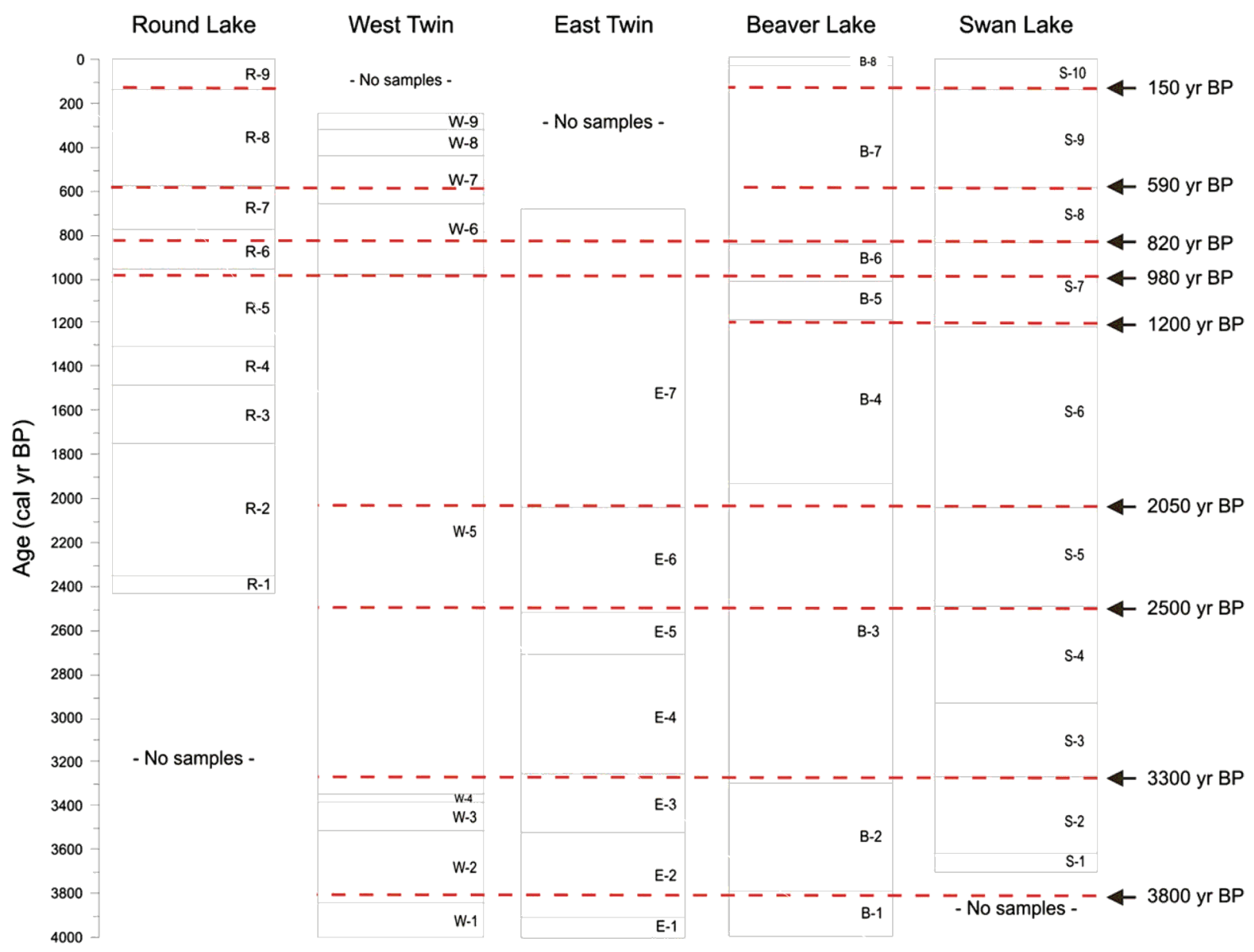

Figure 8. Comparison of diatom zones across all sites. Common intervals of change are represented by the horizontal dashed red bars.

ing $60 \%$ of the entire assemblage, is predominantly made up of A. ambigua, indicating low-light conditions and high $\mathrm{Si} / \mathrm{P}$ ratios (Anderson, 2000). Tychoplanktic species become more prominent between 2150 and $1600 \mathrm{cal}$ a BP, as does F. tenera, which is extremely efficient under low-phosphorus conditions (Interlandi et al., 1999). This shift in the diatom community suggests lower phosphorus recycling from the sediments either due to weaker winds and/or elevated water depth. Overall, benthic diatoms with shallow water optima, such as Gomphonema spp. are the dominant group between $\sim 1600$ and $850 \mathrm{cal}$ a BP. Conditions were probably dry, and abundant attached diatoms indicate macrophytes likely were flourishing. A relatively brief interval at the top of zone S-6, between 1350 and $1250 \mathrm{cal}$ a BP, is characterized by high abundances of $A$. ambigua, signifying higher effective moisture during this time. This is followed by the appearance of moderate percentages of $A$. distans, a planktic species absent from the calibration set, which suggests low alkalinities and shallow water (Brugam and Swain, 2000), perhaps as a result of reduced groundwater input.

At $\sim 850$ cal a BP (zone S-8), sand input increased drastically, which suggests regional eolian activity at the time of the MCA. OSL ages of a discrete sand layer further up-section date to $670 \pm 45$ a BP. Overall, this event coincides with lower diatom diversity and abundance suggesting low effective moisture (Rusak et al., 2004). However, planktic species dominate for most of the zone. In particular small Stephanodiscus spp., Cyclotella spp., and A. granulata simultaneously increase with the sharp rise of sand input at the onset of S-8, suggesting that despite the eolian activity, lake-levels remained relatively stable. The period from 850 to $250 \mathrm{cal}$ a BP (zones S-8 and S-9) is, for the most part, dominated by planktic species, including S. minutulus and A. ambigua, which overall suggests moderate lake-depth. During this period, two major sand influxes briefly interrupt the dominance of planktic diatoms and suggest brief pulses of eolian activity.

\subsection{Spatial and temporal patterns of variation}

The paleolimnological reconstructions from the five sites show that the climate of the last 4000 years was hydrologically complex in this region, with large oscillations in lake-levels. The sites show a moderate degree of coherency in magnitude and pattern of change on long temporal scales, but it is difficult to reconcile the fine-scale (decadal to multi-decadal) behavior of the records, in part because of differences in resolution and age models (Figures $8 \& 9$ ). Spectral analysis from all sites (Schmieder, 2009) did not reveal any clear evidence for common periodicities among the sites, nor did the analysis of individual sites show well-defined frequencies related to common climate forcing, such as solar variability (Bond et al., 2001) or oscillatory modes of sea-surface temperature variation, such as the Pacific Decadal Oscillation (Stone and Fritz, 2006). None-the-less the overall coherence in timing of major shifts in the lake systems suggests that the lakes are responding to large-scale forcing factors, likely related to climate. 


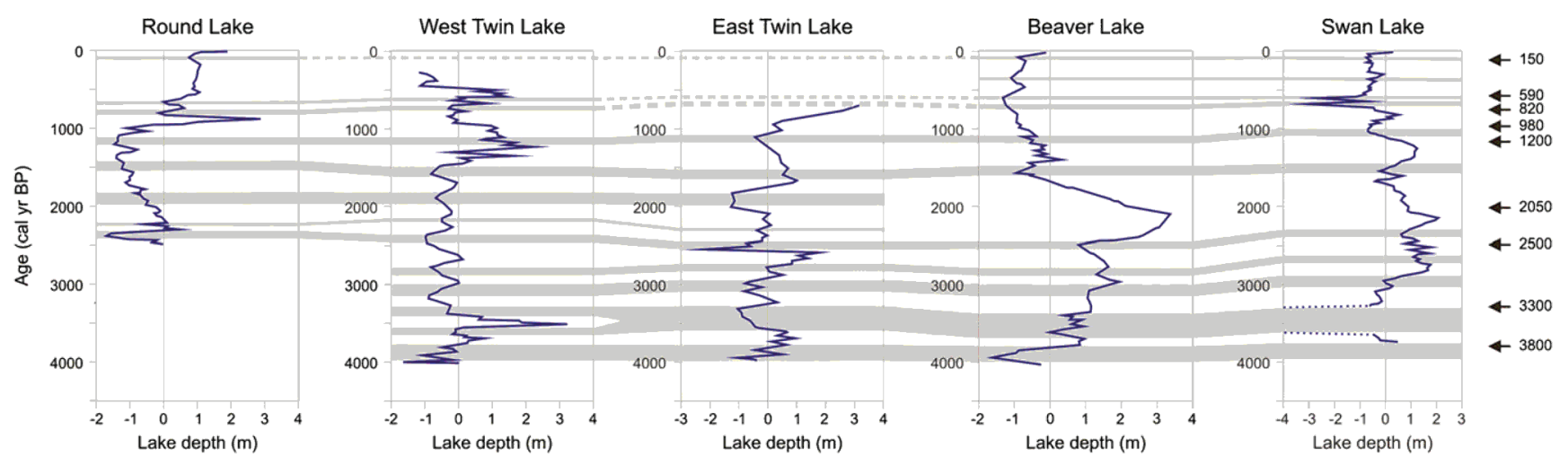

Figure 9. Z-scores of diatom-inferred lake-level histories of all lakes with 20 year interpolated sample spacing for the entire 4000 year record. Vertical lines depict mean depths. Lake-depths to the left of the lines represent inferred intervals of low effective moisture (drought); everything to the right side of the line reflects inferred high effective moisture and wetter conditions. Shaded intervals represent times of drought, and unshaded intervals indicate wetter periods. Arrows represent coherent shifts in diatom assemblages according to the diatom zonation (see Figure 8).

The five lakes investigated in this study are within a uniform physiographic region, however, they span a strong regional gradient in effective moisture, which has the potential to produce spatial variation in drought. In fact, mean precipitation records from 1971-1990 for climate stations closest to each of the lakes indicate a difference of more than $100 \mathrm{~mm}$ between Swan Lake in the east $(597 \mathrm{~mm})$ and Round Lake in the west (479 mm) (http://www.nebraskaclimateoffice.unl.edu/). Effective moisture may have always been higher in the eastern part of the Sand Hills during the Holocene. However, trends and internal stratification of linear dunes in the Sand Hills suggest large-scale wind shifts during the MCA, whereby moist southerly flow from the Gulf of Mexico was replaced by dry southwesterly winds (Sridhar et al., 2006). As a result, the predominant moisture source was reduced, and the modern E-W precipitation gradient may have been altered. Similar shifts in wind direction and moisture transport may have occurred at other periods in the past and played a role in producing intervals of major drought.

Nine major changes in lake-level are synchronous at two or more sites in a spatially coherent pattern based on the diatom zonation (Figure 8). Synchronous shifts in diatom community structure are apparent for the two most recent episodes of inferred drought (150 and $\sim 600 \mathrm{cal} \mathrm{a} \mathrm{BP}$ ) in all lakes but East Twin Lake, which lacks the top portion of the sediment core. At $\sim 820 \mathrm{cal}$ a BP a shift is evident in all lakes except the Twin Lakes. Similarly, at $\sim 980$ cal a BP a shift is documented everywhere but East Twin Lake. At 1200 cal a BP, changes occur exclusively in the western lakes (Round, Twin Lakes), but not in Beaver and Swan Lake. In contrast, at $2050 \mathrm{cal}$ a BP, eastern sites show simultaneous changes in the diatom community structure but not Round Lake and West Twin Lake. At $2500 \mathrm{cal}$ a BP Round, East Twin and Swan Lakes show synchronous floral change, and synchronous change occurs at 3300 and 3800 cal a BP at all sites. In general, the similar patterns in hydrologic behavior of Twin Lakes and Round Lake in comparison with Beaver and Swan Lake at 2050 and $1200 \mathrm{cal}$ a BP suggest an E-W gradient in response. Between 1000 and $900 \mathrm{cal} \mathrm{a} \mathrm{BP}$ and at around $800 \mathrm{cal} \mathrm{a} \mathrm{BP}$, changes in the diatom community and inferred lake-levels appear slightly earlier in the more western sites.

In a few cases, the lakes do not exhibit clear spatial patterns or temporal synchrony. These individualistic responses may be related to the dune topography and slope discontinuities (Gosselin et al., 1999), as well as lake location in relation to the groundwater flow paths (Gosselin et al., 2006). Over time, dune blockages can raise the water table and lake-levels during extended drought periods (Loope et al., 1995; Ma- son et al., 1997) in areas where the geomorphology is suitable. Thus, localized dune migration(s) at individual sites may have changed the depth to groundwater and/or patterns of groundwater flow thereby producing changes in lake-level that are not evident in other systems. As a result of such localized influences, hydrologic changes may be related to changes in effective moisture in complex ways (Digerfeldt et al., 1993; Fritz et al., 2000; Telford et al. 1999), and it is necessary to carefully examine multiple sites, as well as calibrate and model lake dynamics, in order to better constrain the nature of climate change based on lake records (Fritz, 2008).

\subsection{Comparison of lake sites with other regional records of climate change, particularly eolian records}

Several reconstructions of regional eolian history are available for the Sand Hills region. Nicholson and Swinehart (2005) describe findings from a single location (Jumbo Valley), an interdunal wetland about $7 \mathrm{~km}$ east of Round Lake and $1 \mathrm{~km}$ west of the Twin Lakes (Nicholson and Swinehart, 2005). Goble et al. (2004) and Miao et al. (2007) utilized multiple sites across the Sand Hills region for their reconstructions and present composite trends. Like the lake records, the eolian records show spatial variability in the timing of inferred drought. For example, the period from $\sim 2200$ to $1000 \mathrm{cal}$ a BP was a time when dunes were relatively stable according to Miao et al. (2007), whereas eolian activity was reported from Jumbo Valley (2100-1800 cal a BP, see Figure 1). In any case, our records are in broad agreement with the existing upland dune record of the Sand Hills (e.g. Miao et al., 2007; Figure 10).

The diatom-inferred lake-level curves and a composite $z$ score curve show higher frequency variability in the regional climate than evident in the eolian studies. In particular between 4000 and $2200 \mathrm{cal}$ a BP, our study suggests five distinct drought events of multi-decadal scale and two droughts of multi-centennial scale, whereas the eolian compilations report only two broad arid intervals during the same period (Nicholson and Swinehart, 2005; Miao et al., 2007). The lake-level reconstructions also show that in between these multi-decadal to centennial-scale arid periods were equally long discrete wet phases. The eolian syntheses (Miao et al., 2007) suggest limited eolian activity from $\sim 2200$ to $1200 \mathrm{cal}$ a BP, and this correlates with a period of less frequent and shorter intervals of lake-level decline. The lake records indicate droughts at ca 2000-1900, 1650-1450, 1400, and $1300 \mathrm{cal}$ a BP, occurring during a period of overall higher lake-levels and effective moisture. The comparison of lake and eolian records from 2200 to $1200 \mathrm{cal}$ a BP suggests that the duration and/or frequency of 


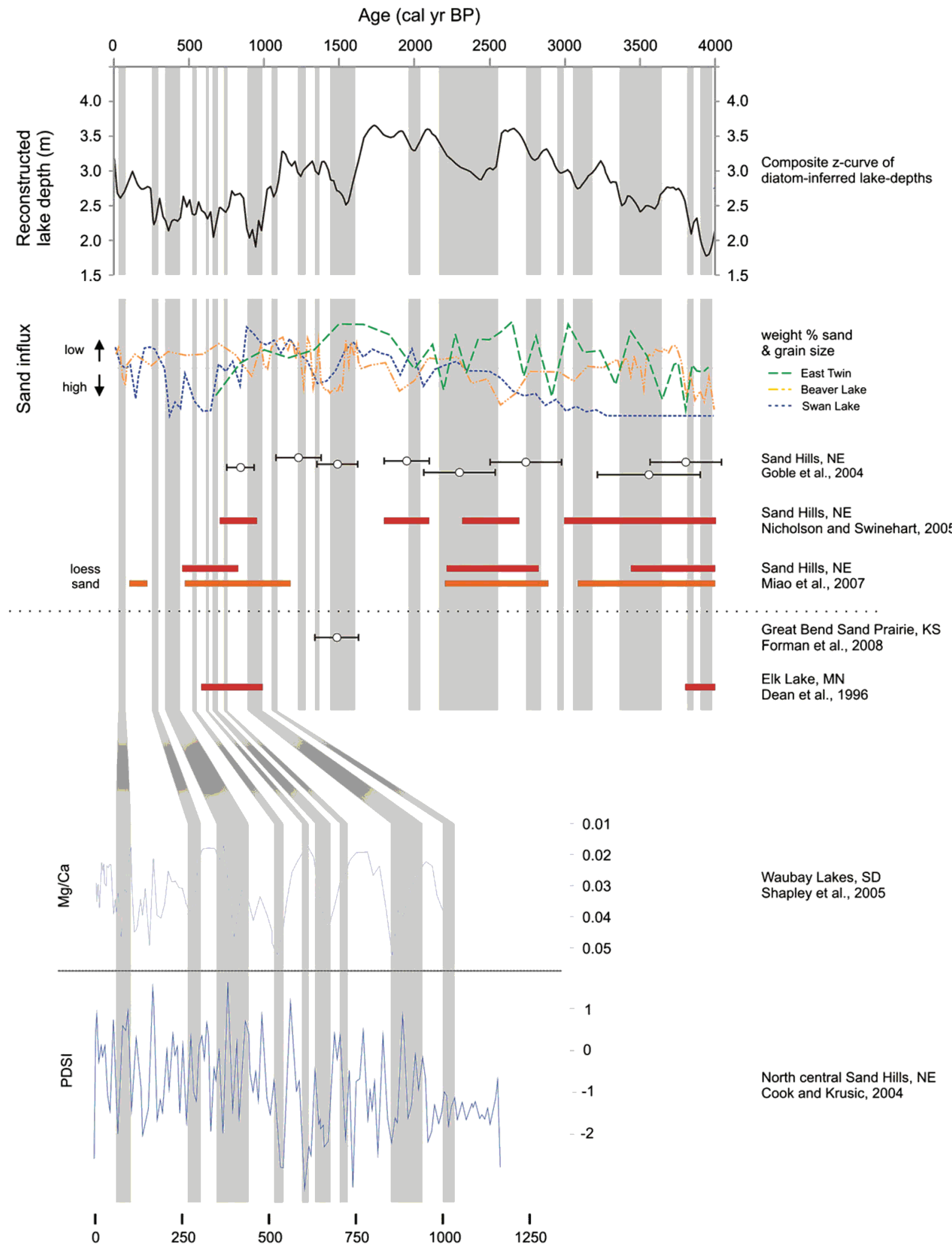

Figure 10. Summary figure showing composite $z$-score curves and inferred regional drought episodes (vertical gray bars) compared with a compilation of the latest OSL results from the Nebraska Sand Hills (Mason et al. 1997; Goble et al., 2004; Miao et al., 2005, 2007), as well as with a number of other regional and continental paleoclimatic records. The number of vertical gray bars is based on time equivalent events of both lake-level fall and increased sand input across multiple sites. OSL ages from Goble et al. (2004) and Forman et al. (2008) are shown with error bars, while droughts inferred from OSL ages from Miao et al. (2007) are represented by horizontal bars identical to those from wetland studies (Dean, 1974 and Nicholson and Swinehart, 2005). The bottom graph compares results of this paper with the PDSI record of the north-central Sand Hills and the ostracode-derived $\mathrm{Mg} / \mathrm{Ca}$ data from South Dakota for the last $1200 \mathrm{cal}$ yr BP. 
drought may have not been sufficient to mobilize dunes on a large-scale. The last 1200 a of the lake records suggest higher frequency variability in the climate relative to the period prior to 2200 cal a BP, with at least three spatially coherent drought episodes (Figure 9), and at least seven more locally restricted drought episodes (Figure 10). Within this period, the most recent interval of widespread eolian activity was the MCA from $\sim 1000$ to $750 \mathrm{cal}$ a BP, and all the lake sites show lake-level decline in this interval, confirming evidence of substantial regional declines in the water table.

\subsection{Other records from the Great Plains and Western U.S.}

In general, prior to $\sim 4000$ years $\mathrm{BP}$, the mid-continent was more arid and also warmer than today (Kutzbach and Ruddiman, 1993; Dean et al., 1996). Higher effective moisture in combination with cooler temperatures characterized the region afterward (Webb et al., 1993). Despite a cooling trend and higher effective moisture, a variety of proxy climate data indicate that severe droughts affected much of the western United States and the Great Plains during the last few thousand years (e.g. Laird et al., 1996, 1998, 2007; Woodhouse and Overpeck, 1998; Forman et al., 2001; Cook et al., 2004; Daniels and Knox, 2005). The dominant moisture fluctuations documented in this study appear to have affected a large portion of mid-continental U.S. over the last 4000 years. Specifically, a widespread geographic distribution is apparent for droughts that occurred between 4000-3000, 1500, 1200, and 1000-700 cal a BP (Figure 10).

During the last 2000 years, widespread and extensive drought has been reported from multiple sites across western America, including documented eolian activity in the central and northern Great Plains (Forman et al., 2000) that overlaps in timing with the inferred lake-level declines in the Nebraska Sand Hills. Radiocarbon ages from paleosols of the Minot Dune Field in north Dakota places the oldest recognized dune event just prior to $1300-1100$ cal a BP, with two subsequent younger dune migration events at about 1000 and $600 \mathrm{cal}$ a BP (Muhs et al., 1997). In northeastern Colorado, paleosols found within eolian sands provide evidence for eolian activity at around 1400, 1050, and 900 cal a BP (Madole, 1995; Muhs et al., 1997).

It is difficult to confidently compare high-frequency (decadal to multi-decadal) late-Holocene variability in the Nebraska lake records to other high-resolution lake and tree-ring records, because of the inherent errors associated with radiocarbon derived chronologies. Nonetheless, the major dry periods inferred from the Sand Hills lakes during the last 2000 years in most cases correlate well (Figure 10) with dry intervals inferred from diatom-inferred salinity reconstructions and ostracode- $\mathrm{Mg} / \mathrm{Ca}$ ratios from lake sediments in the northern Great Plains (Laird et al., 2003; Shapley et al., 2005). with the increased influx of eolian-derived clastic material in sediments of Elk Lake in north-central Minnesota centering around $800 \mathrm{cal}$ a BP (Dean et al., 1996); and with drought reconstructions from the north-central Sand Hills and other parts of the Western US (Cook et al., 2004; Cook and Krusic, 2004). Evident in all of these records are the prominent Medieval droughts between 1000 and $700 \mathrm{cal}$ a BP (sometimes called megadroughts) that extended across much of the western United States (Cook et al., 2004).

The Sand Hill lake records suggest that climate of the last $\sim 1300$ years may have been wetter in the Western part of the region and drier in the central and eastern Sand Hills relative to prior times (Figure 10). Although this inference is based on a limited number of sites, the increased moisture during the last $\sim 1300$ a in Westernmost Nebraska resembles the pattern evident in lacustrine high-resolution records of drought variability from the northern Rocky Mountain region, an area that is more strongly influenced by Pacific moisture sources. At Foy Lake in eastern Montana, consistently lower lake-levels occurred between 2300 and $1300 \mathrm{cal}$ a BP and generally higher lake-stands were present between $1300 \mathrm{cal}$ a BP to the present (Stevens et al., 2006). Similarly, two lake records in the Beaverhead Mountains of western Montana, as well as Crevice Lake in Yellowstone National Park, showed higher effective moisture after $\sim 1300$ cal a BP (Bracht et al., 2008; Bracht, 2010). Thus, there is a suggestion of an overall increase in precipitation during the last approximately thousand years in regions influenced by Pacific moisture sources.

Similarities in the duration and frequency of diatom-inferred hydrologic events between Sand Hills lakes and other records of the Great Plains are apparent, and we can propose correspondence of major climatic events in the regional record with some confidence.

Although a spectral analysis did not clearly reveal any frequencies related to oscillatory patterns of sea-surface temperature variation, the mechanisms behind these climatic fluctuations are probably related to changes in the Pacific and Atlantic sea-surface temperatures that altered atmospheric circulation patterns across America (McCabe et al., 2004; Seager et al., 2007). The east- or southward migration of the North Atlantic subtropical high-pressure ridge ("Bermuda High") was likely responsible for the replacement of moisture-laden southerly winds from the Gulf of Mexico with dry southwesterly winds in the Sand Hills during the MCA (Sridhar et al., 2006), and it is likely that similar changes in wind regimes played a key role in earlier Holocene droughts across the Great Plains.

\section{Conclusions}

Our synthesis of multiple sites across the Nebraska Sand Hills indicates that droughts of varying intensity and frequency have been a common feature in this region for at least the last four thousand years. Though complex and locally variable, these records can begin to answer questions about regional drought during the Holocene.

\section{Are there common intervals of change among the five study sites?} If so, do they show similar changes or site-specific responses?

Our study shows that the majority of large-scale multi-centennial shifts exhibit regional coherency, albeit of varying magnitude and duration. In some intervals of time the eastern lakes show a response that differs from the western sites, which suggests that the pattern of the east to west precipitation gradient varied through time. There is considerably more spatial variability at decadal to multi-decadal scales, which may reflect spatially variable precipitation patterns or alternatively differences in hydrological setting and the response of local hydrology to changing dune morphology and effective moisture. Centennial-scale droughts were more frequent prior to $2000 \mathrm{cal}$ a BP, while the last 2000 years exhibited more highfrequency variability with generally shorter drought periods.

\section{How do these lake records compare with other regional records of} climate change, particularly the eolian records?

Overall, the eolian drought record of the Sand Hills is broadly consistent with our results, in particular with respect to the larger-scale "megadroughts". However, this study provides a continuous record spanning the last 4000 years at a much higher resolution. As a result, we were able to identify a number of regionally coherent shorter-term droughts, which did not necessarily lead to dune mobilization. Such "minidroughts" have therefore not left any significant records in eolian sediments. 
3. How do these records relate to other records from the Great Plains and Western U.S., and what does this suggest about environment and climate?

Similarities in duration and frequency of diatom-inferred hydrologic events between Sand Hills lakes and other records from the Great Plains are apparent. Lacustrine high-resolution records from the northern Rocky Mountain region of the U.S. show trends that are more similar to the westernmost sites in our study area, and these records collectively suggest an overall increase in precipitation during the last thousand years or so in regions predominantly influenced by Pacific moisture sources.

Overall, our findings refine the existing upland drought record in the Sand Hills and improve our understanding of lateHolocene climate variability across the region. At the same time, this study raises awareness of the complex hydrologic settings in the Sand Hills lakes and their intimate relationship to the stability of the surrounding dune landscape.

\section{Author contributions}

This research project was a collaborative effort. J. Schmieder undertook analysis and interpretation of the majority of diatom, sedimentological, and geochemical samples discussed here and took primary responsibility for writing the manuscript. S. Fritz provided the research idea and funding and helped with valuable feedback on data interpretation and the manuscript in varied stages of development. J. Swinehart was the leading force in the field and offered many constructive ideas that improved this research project from its conception to completion. Avery Cook Shinneman helped with the ordination of modern diatom surface-sample data and the transfer functions for reconstruction of lake-depth and provided valuable feedback for the manuscript. A. Wolfe, G. Miller, and N. Daniels cored Round Lake and provided the diatom counts. $\mathrm{K}$. Jacobs counted the majority of the diatom samples from Beaver Lake, and E. Grimm collected the Beaver Lake sediment core and carried out the radiocarbon dating at that site.

Acknowledgments - This work was funded by the Sand Hills Biocomplexity Project at the University of Nebraska-Lincoln (NSF-02167), by NSF grant (EAR06-02154) to S. Fritz and E. Grimm, and an NSF grant (EAR06-09982) to V. Zlotnik, S. Fritz, and J. Swinehart. Additional funding was provided through the Department of Geosciences of the University of Nebraska, the Yatkola-Edwards Grant of the Nebraska Geological Society, and the Great Plains Studies Research Grant-in-Aid. G. H. Miller, A. P. Wolfe, and N. Daniels acknowledge financial support from NASA grant NAG5-6051. Field assistance at Swan Lake was provided by Aaron Young. Thanks goes to Stefan Kollet for the grain-size analysis of Beaver Lake and Ron Goble for processing the OSL samples.

\section{References}

Appleby, P. G., 2001. Chronostratigraphic techniques in recent sediments. In: Last, W. M., Smol, J. P. (eds.), Tracking Environmental Change Using Lake Sediments. Kluwer, Dordrecht, pp. 171-201.

Ahlbrandt, T. S., Fryberger, S. G., 1980. Geologic and paleoecologic studies of the Nebraska Sand Hills: US Geological Survey Professional Paper 1120-A, 28.

Anderson, N. J., 2000. Diatoms, temperature and climate change. European Journal of Phycology 35, 307-314.

Battarbee, R. W., 1986. Diatom analysis. In: Berglund, B. (ed.), Handbook of Holocene Paleoecology and Paleohydrology. Wiley, pp. 527-570.

Bennett, K. D., 2002. Documentation for Psimpoll 4.10 and Pscomb 1.03. http://www.kv.geo.uu.se/psimpoll.htm

Bennett, D. M., Fritz, S. C., Holz, J., Holz, A., Zlotnik, V., 2007. Evaluating climatic and non-climatic influences on natural and man-made lakes in Nebraska, USA. Hydrobiologica 591, 103-115.

Bond, G., Kromer, B., Beer, J., Muscheler, R., Evans, M. N., Showers, W., Hoffmann, S., Lotti-Bond, R., Hajdas, I., Bonani, G., 2001. Persistent solar influence on North Atlantic climate during the Holocene. Science 294, 2130-2136.
Bradbury, J. P., 1988. A climatic-limnologic model of diatom succession for paleolimnological interpretation of varved sediments at Elk Lake, Minnesota. Journal of Paleolimnology 1, 115-132.

Bracht, B. B., Stone, J. R., Fritz, S. C., 2008. A diatom record of late-Holocene climate variation in the northern range of Yellowstone National Park, USA. Quaternary International 188, 149-155.

Bracht, B. B. 2010. Evaluating lake response to environmental and climate change using lake core records and modeling. PhD thesis, University of Nebraska-Lincoln.

Brugam, R. B., Speziale, B. J., 1983. Human disturbance and the paleolimnological record of change in the zooplankton community of Lake Harriet, Minnesota. Ecology 64, 578-591.

Brugam, R. B., Swain, P., 2000. Diatom indicators of peatland development at Pogonia Bog Pond, Minnesota, USA. The Holocene 10, 453-464.

Cook, E. R., Krusic, P. J., 2004. The North American Drought Atlas. Lamont-Doherty Earth Observatory and the National Science Foundation. http://iridl.ldeo.columbia.edu/SOURCES/.LDEO/.TRL/. NADA2004/.pdsi-atlas.html

Cook, E. R., Woodhouse, C. A., Eakin, C. M., Meko, D. M., Stahle, D. W., 2004. Long-term aridity changes in the western United States. Science 306, 1015-1018.

Cumming, B. F., Wilson, S. E., Hall, R. I., Smol, J. P., 1995. Diatoms from British Columbia (Canada) and their relationship to salinity, nutrients and other limnological variables. Bibliotheca Diatomologica 31, 207. Stuttgart, Germany

Daniels, N., 2001. Diatom-inferred salinity changes and drought history of the last 3000 years from Round Lake, Nebraska. M. Sc. thesis, University of Colorado, Boulder, USA

Daniels, J. M., Knox, J. C., 2005. Alluvial stratigraphic evidence for channel incision during the Mediaeval Warm Period on the central Great Plains, USA. The Holocene 15, 736-747.

Davis, R. B., Anderson, D. S., Norton, S. A., Ford, J., Sweets, P. R., Kahl, J. S., 1994. Sedimented diatoms in northern New England lakes and their use as $\mathrm{pH}$ and alkalinity indicators. Canadian Journal of Fisheries and Aquatic Science 51, 1855-1876.

Dean, W. E., 1974. Determination of carbonate and organic matter in calcareous sediments and sedimentary rocks by loss on ignition: Comparison with other methods. Journal of Sedimentary Petrology 44, 242-248.

Dean, W. E., Ahlbrandt, T. S., Anderson, R. Y., Bradbury, J. P., 1996. Regional aridity in north America during the middle Holocene. The Holocene 6, 145-155.

Forman, S. L., Oglesby, R., Webb, R. S., 2001. Temporal and spatial patterns of Holocene dune activity on the Great Plains of North America; Megadroughts and climate links. Global and Planetary Change 29, 1-29.

Forman, S. L., Marín, L., Pierson, J., Gómez, J., Miller, G. H., Webb, R. S., 2005. Aeolian sand depositional records from western Nebraska: landscape response to droughts in the past 1500 years. The Holocene 15, 973-981.

Forman, S. L., Marín, L., Gomez, J., Pierson, J., 2008. Late Quaternary eolian depositional record for southwestern Kansas: Landscape sensitivity to droughts. Paleogeography, Paleoclimatology, Paleoecology 265, $107-120$.

Fritz, S. C., 2008. Deciphering climatic history from lake sediments. Journal of Paleolimnology 39, 5-16.

Fritz, S. C., Cumming, B. F., Gasse, F., Laird, K. R., 2010. Diatoms as indicators of hydrologic and climatic change in saline lakes. In: Smol, J. P., Stoermer, E. F. (eds.), The Diatoms: Applications to Environmental and Earth Sciences, second ed. Cambridge University Press, London, pp. $186-208$.

Fritz, S. C., Ito, E., Yu, Z., Laird, K. R., Engstrom, D. R., 2000. Hydrologic variation in the northern Great Plains during the last two millennia. Quaternary Research 53, 175-184.

Goble, R. J., Mason, J. A., Loope, D. B., Swinehart, J. B., 2004. Optical and radiocarbon ages of stacked paleosols and dune sands in the Nebraska Sand Hills, USA. Quaternary Science Reviews 23, 1173-1182.

Gosselin, D. C., 1997. Major ion chemistry of compositionally diverse lakes, Western Nebraska, U.S.A.: Implications for paleoclimatic interpretations. Journal of Paleolimnology 17, 33-49.

Gosselin, D. C., Drda, S., Harvey, F. E., Goeke, J., 1999. Hydrologic setting of two interdunal valleys in the Central Sand Hills of Nebraska. Ground Water 37, 924-932.

Gosselin, D. C., Sridhar, V., Harvey, F. E., 2006. Hydrological effects and groundwater fluctuations in interdunal environments in the Nebraska Sand Hills. Great Plains Research 16, 17-28.

Håkansson, H., Kling, H., 1989. A light and electron microscope study of previously described and new Stephanodiscus species (Bacillariophyceae) from central and northern Canada lakes, with ecological notes on the species. Diatom Research 4, 269-288.

Interlandi, S. J., Kilham, S. S., Theriot, E. C., 1999. Responses of phytoplankton to varied resource availability in large lakes of the Greater Yellowstone Ecosystem. Limnology and Oceanography 44, 668-682. 
Juggins, S., 2003. C2 user guide. Software for ecological and palaeoecological data analysis and visualisation. University of Newcastle upon Tyne, p. 69.

Krammer, K., Lange-Bertalot, H., 1986-1991. Bacillariophyceae. In: Ettl, H., Gerloff, J., Heynig, H., Mollenhauer, D. (eds.), Süsswasserflora von Mitteleuropa, Band 2 (1-4). Gustav Fischer Verlag, Stuttgart/Jena.

Kutzbach, J. E., Ruddiman, W. F., 1993. Model description, external forcing, and surface boundary conditions. In: Global Climates Since the Last Glacial Maximum. University of Minnesota Press, p. 563.

Laird, K. R., Fritz, S. C., Cumming, B. F., 1996. Greater drought intensity and frequency before AD 1200 in the Northern Great Plains, USA. Nature 384, 552-555.

Laird, K. R., Fritz, S. C., Cumming, B. F., Grimm, E. C., 1998. Early-Holocene limnological and climatic variability in the Northern Great Plains. The Holocene 8, 275-285.

Laird, K. R., Cumming, B. F., Wunsam, S., Rusak, J. A., Oglesby, R. J., Fritz, S. C., Leavitt, P. R., 2003. Lake sediments record large-scale shifts in moisture regimes across the northern prairies of North America during the past two millennia. Proceedings of the National Academy of Sciences 100, 2483-2488.

Laird, K. R., Michels, A., Stuart, C. T. L., Wilsona, S. E., Last, W. M., Cumming, B. F., 2007. Examination of diatom-based changes from a climatically sensitive prairie lake (Saskatchewan, Canada) at different temporal perspectives. Quaternary Science Reviews 26, 3328-3343.

Last, M., Smol, J. P., 2001. Tracking Environmental Change Using Lake Sediments. Vol. 1: Basin Analysis, Coring and Chronological Techniques. Kluwer Academic Publishers, Netherlands.

La Baugh, J. W., 1986. Limnological characteristics of selected lakes in the Nebraska Sand hills, USA, and their relations to chemical characteristics of adjacent ground water. Journal of Hydrology 86, 279-298.

Loope, D. B., Swinehart, J. B., Mason, J. P., 1995. Dune-dammed paleovalleys of the Nebraska Sand Hills: intrinsic versus climatic controls on the accumulation of lake and marsh sediments. Geological Society of America Bulletin 107, 396-406.

Loope, D. B., Swinehart, J. B., 2000. Thinking like a dune field: Geological history in the Nebraska Sand Hills. Great Plains Research 10, 5-35.

Madole, R. F., 1995. Spatial and temporal patterns of late Quaternary eolian deposition, eastern Colorado, U. S. A. Quaternary Science Reviews $14,155-177$.

Mason, J. B., Swinehart, J. B., Loope, D. B., 1997. Holocene history of lacustrine and marsh sediments in a dune-blocked drainage, southwestern Nebraska Sand Hills, USA. Journal of Paleolimnology 17, 67-83.

Mann, M. E., Lees, J., 1996. Robust estimation of background noise and signal detection in climatic time series. Climate Change 33, 409-445.

McCarraher, D. B., 1977. Nebraska's Sand Hills Lakes. Nebraska Games and Parks Commission.

Miao, X., Mason, J. A., Goble, R. J., Hanson, P. R., 2005. Loess record of dry climate and eolian activity in the early- to mid-Holocene, central Great Plains, North America. The Holocene 15, 339-346.

Miao, X., Mason, J. P., Swinehart, J. B., Loope, D. B., Hanson, P. R., Goble, R. J., Liu, X., 2007. A 10,000 year record of dune activity, dust storms, and severe drought in the central Great Plains. Geology 35, 119-122.

Muhs, D. R., Maat, P. B., 1993. The potential response of eolian sand to greenhouse warming and precipitation reduction on the Great Plains of the U.S.A. Journal of Arid Environments 25, 351-361.

Muhs, D. R., Stafford, T. W. J., Been, J., Mahan, S., Burdett, J., Skipp, G., Muhs Rowland, Z., 1997. Holocene eolian activity in the Minot dune field, North Dakota. Canadian Journal of Earth Science 34, 1442-1459.

Murray, A. S., Wintle, A. G., 2000. Luminescence dating of quartz using an improved single-aliquot regenerative-dose protocol. Radiation Measurements 32, 57-73.

Nicholson, B. J., Swinehart, J. B., 2005. Evidence of Holocene climate change in a Nebraska Sandhills wetland. Great Plains Research 15, 45-67.

Paillard, D., Labeyrie, L., Yiou, P., 1996. Macintosh program performs timeseries analysis. Eos 77, 379.

Patrick, R., Reimer, C., 1966. The Diatoms of the United States Exclusive of Alaska and Hawaii. Vol. 1. The Academy of Natural Sciences of Philadelphia, Philadelphia, Monograph 13, pp. 668.

Patrick, R., Reimer, C., 1975. The Diatoms of the United States Exclusive of Alaska and Hawaii. Vol. 2, Part 1. The Academy of Natural Sciences of Philadelphia, Philadelphia, Monograph 13, pp. 213.

Reavie, E. D., Smol, J. P., Charmichael, N. P., 1995. Post settlement eutrophication histories of six British Columbia (Canada) lakes. Canadian Journal of Fisheries and Aquatic Sciences 52, 2388-2401.

Rundquist, D. C., 1983. Wetland Inventories of Nebraska's Sandhills. Resource Report. University of Nebraska, Lincoln; Conservation and Survey Division, 9, pp. 46.

Rusak, J. A., Leavitt, P. R., McGowan, S., Chen, G., Olson, O., Wunsam, S., Cumming, B. F., 2004. Millennial-scale relationships of diatom species richness and production in two prairie lakes. Limnology and Oceanography $49,1290-1299$.
Salm, C. R., Saros, J. E., Fritz, S. C., Osburn, C. L., Reineke, D. M., 2009 Phytoplankton productivity across prairie saline lakes of the Great Plains (USA): a step toward deciphering patterns through lake classification models. Canadian Journal of Fisheries and Aquatic Sciences 66, $1435-1448$.

Schmieder, J., 2009. The Nebraska Sand Hills-Mid to Late Holocene drought variation and landscape stability based on high-resolution lake sediment records. PhD dissertation, University of Nebraska, Lincoln, USA.

Schnagl, J. A., 1980. Seasonal variations in water chemistry and primary productivity in four alkaline lakes in the Sandhills of western Nebraska. M.S. thesis. University of Nebraska-Lincoln, USA.

Seager, R., Ting, M., Held, I., Kushnir, Y., Lu, J., Vecchi, G., Huang, H., Harnik, N., Leetmaa, A., Lau, N., Li, C., Velez, J., Naik, N., 2007. Model projections of an imminent transition to a more arid climate in southwestern North America. Science 316, 1181-1184.

Shapley, M. D., Johnson, W. C., Engstrom, D. R., Osterkamp, W. R., 2005 Late-Holocene flooding and drought in the Northern Great Plains, USA reconstructed from tree rings, lake sediments and ancient shorelines. The Holocene 15, 29-41.

Shinneman, A. C., Bennett, D. M., Fritz, S. C., Schmieder, J., Engstrom, D. R., Efing, A., Holz, J., 2010. Inferring lake depth using diatom assemblages in the shallow, seasonally variable lakes of the Nebraska Sand Hills (USA); calibration, validation, and application of a 69-lake training set. Journal of Paleolimnology 44, 443-464.

Sridhar, V., Loope, D. B., Swinehart, J. B., Mason, J. P., Oglesby, R. J., Rowe, C. M., 2006. Large wind shift on the Great Plains during the medieval warm period. Science 313, 345-347.

Steinauer, G., Rolfsmeier, S., Hardy, J. P., 1996. Inventory and floristics of Sandhills fens in Cherry County, Nebraska. Transactions of the $\mathrm{Ne}-$ braska Academy of Sciences 23, 9-21.

Stevens, L. R., Stone, J. R., Campbell, J., Fritz, S. C., 2006. A 2200 year record of hydrologic variability from Foy Lake, Montana, USA, inferred from diatom and geochemical data. Quaternary Research 65, 264-274.

Stokes, S., Swinehart, J. B., 1997. Middle- and late-Holocene dune reactivation in the Nebraska sand Hills, U. S. A. The Holocene 35, 263-272.

Stone, J. R., Fritz, S. C., 2006. Multi-decadal drought frequency and Holocene drought instability in the northern Rocky Mountains. Geology 34, 409-412.

Stuiver, M., Reimer, P. J., 1993. Extended ${ }^{14} \mathrm{C}$ data base and revised CALIB 3. $0^{14} \mathrm{C}$ age calibration program. Radiocarbon $35,215-230$.

Swinehart, J. B., 1990. Windblown deposits. In: Bleed, A., Flowerday, C. (eds.), An Atlas of the Sand Hills. Conservation and Survey Division University of Nebraska-Lincoln, pp. 43-56. Resource Atlas 5b. Lincoln.

Telford, R. J., Lamb, H. F., Mohammed, M. U., 1999. Diatom-derived paleoconductivity estimates for Lake Awassa, Ethiopia: Evidence for pulsed inflows of saline groundwater? Journal of Paleolimnology 21, 409-421.

Theriot, E., Stoermer, E. F., 1981. Some aspects of morphological variation in Stephanodiscus niagarae (Bacillariophyceae). Journal of Phycology 17, 64-72.

Theriot, E., 1987. Principal component analysis and taxonomic interpretation of environmentally related variation in silicification in Stephanodiscus (Bacillariophyceae). British Phycological Journal 22, 359-373.

Timer, R. W., 2003. Geographically isolated wetlands of the United States. Wetlands 23, 494-516.

Webb, T. I., Bartlein, P. J., Harrison, S. P., Anderson, K. H., 1993. Vegetation lake-levels, and climate in eastern North America for the past 18,000 years. In: Wright, H. E., Kutzbach, III, J. E., Webb, T., Ruddiman, W. F., Street-Perrott, F. A., Bartlein, P. J. (eds.), Global Climates Since the Last Glacial Maximum. University of Minnesota Press, Minneapolis, pp. 415-467.

Wilhite, D. A., Hubbard, K. G., 1998. Climate. In: Bleed, A., Flowerday, C. (eds.), An Atlas of the Sand Hills. Conservation and Survey Division, University of Nebraska-Lincoln, pp. 17-28. Resource Atlas 5b. Lincoln.

Wilson, S. E., Cumming, B. F., Smol, J. P., 1996. Assessing the reliability of salinity inference models from diatom assemblages: an examination of a 219-lake data set from western North America. Canadian Journal of Fisheries and Aquatic Sciences 53, 1580-1594.

Woodhouse, C. A., Overpeck, J. T., 1998. 2000 years of drought variability in the Central United States. Bulletin of the American Meteorological Society 79, 2693-2714.

Zlotnik, V. A., Burbach, M., Swinehart, J., Bennett, D., Fritz, S. C., Loope, D. B., Olaguera, F., 2007. A case study of direct push methods for aquifer characterization in dune-lake environments. Environmental and Engineering Geology 3, 205-216. 